\title{
EVALUATION OF RECHARGE POTENTIAL AT CRATER U5a (WISHBONE)
}

\author{
prepared by
}

Samuel L. Hokett and Richard H. French

submitted to

Nevada Operations Office

U.S. Department of Energy

November 1998 
This report was prepared as an account of work sponsored by the United States Government. Neither the United States nor the United States Department of Energy, nor any of their employees, nor any of their contractors, subcontractors or their employees, makes any warranty, express or implied, or assumes any legal liability or responsibility for the accuracy, completeness, or any third party's use or the results of such use of any information, apparatus, product, or process disclosed, or represents that its use would not infringe privately owned rights. Reference herein to any specific commercial product, process, or service by trade name, trademark, manufacturer, or otherwise, does not necessarily constitute or imply its endorsement, recommendation, or favoring by the United States Government or any agency thereof or its contractors or subcontractors. The views and opinions of authors expressed herein do not necessarily state or reflect those of the United States Government or any agency thereof.

This report has been reproduced directly from the best available copy.

Available to the public from:

U.S. Department of Commerce

National Technical Information Service

5285 Port Royal Road

Springfield, VA 22161

(703) 487-4650

Available electronically at $h t t p: / / w w w . d o e . g o v / b r i d g e$

Available to the U.S. Department of Energy and its contractors in paper from:

U.S. Department of Energy

Office of Scientific and Technical Information

P.O. Box 62

Oak Ridge, TN 37831

(423) 576-8401 


\title{
EVALUATION OF RECHARGE POTENTIAL AT CRATER U5a (WISHBONE)
}

\author{
Prepared by \\ Samuel L. Hokett and Richard H. French \\ Water Resources Center \\ Desert Research Institute \\ University and Community College System of Nevada \\ Publication No. 45160
}

Submitted to

Nevada Operations Office

U.S. Department of Energy

Las Vegas, Nevada

November 1998

The work upon which this report is based was supported by the U.S. Department of Energy under Contract \#DE-AC08-95NV11508. Approved for public release; further dissemination unlimited. 


\begin{abstract}
Radionuclides are present both below and above the water table at the Nevada Test Site (NTS), as the result of underground nuclear testing. Mobilization and transport of radionuclides from the vadose zone is a complex process that is influenced by the solubility and sorption characteristics of the individual radionuclides, as well as the soil water flux. On the NTS, subsidence craters resulting from testing underground nuclear weapons are numerous, and many intercept surface water flows. Because craters collect surface water above the sub-surface point of device detonation, these craters may provide a mechanism for surface water to recharge the groundwater aquifer system underlying the NTS. Given this situation, there is a potential for the captured water to introduce contaminants into the groundwater system. Crater U5a (WISHBONE), located in Frenchman Flat, was selected for study because of its potentially large drainage area, and significant erosional features, which suggested that it has captured more runoff than other craters in the Frenchman Flat area. Recharge conditions were studied in subsidence crater U5a by first drilling boreholes and analyzing the collected soil cores to determine the soil properties and moisture conditions. This information, coupled with a 32-year precipitation record, was used to conduct surface and vadose zone modeling. Surface water modeling predicted that approximately 13 ponding events had occurred during the life of the crater. Vadose zone modeling indicated that since the crater's formation approximately $5,900 \mathrm{~m}^{3}$ of water were captured by the crater. Of this total, approximately $5,200 \mathrm{~m}^{3}$ of potential recharge may have occurred, and the best estimates of annual average potential recharge rates lie between 36 and $118 \mathrm{~cm}$ of water per year. The term potential is used here to indicate that the water is not technically recharge because it has not yet reached the water table. Using a conservative conceptual model (worst-case scenario for deep movement of moisture), the wetting front may have reached a depth of approximately $130 \mathrm{~m}$ below the crater bottom. Wetting front advancement occurred almost exclusively following ponding events, indicating that without additional ponding events, movement of the wetting front would slow down dramatically or for all practical purposes stop. Modeling indicates that to date, water has not yet intersected the water table. Additionally, if contaminates are transported to the water table, the hydrology of Frenchman Flat is such that transport off of the NTS would likely require thousands of years.
\end{abstract}




\section{CONTENTS}

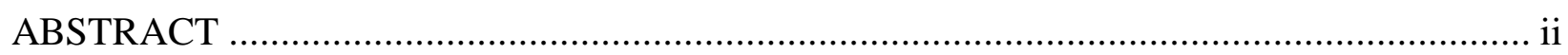

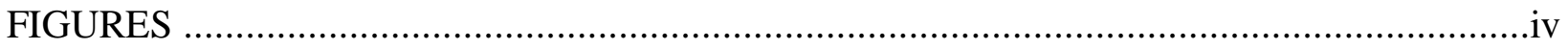

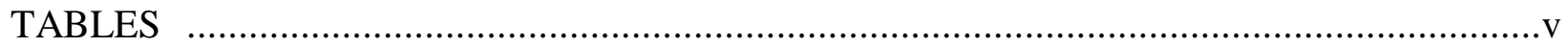

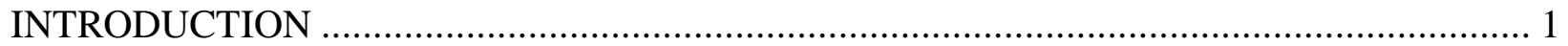

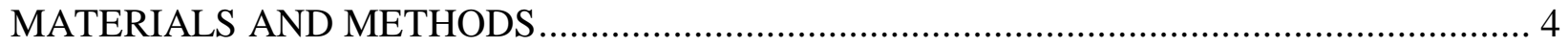

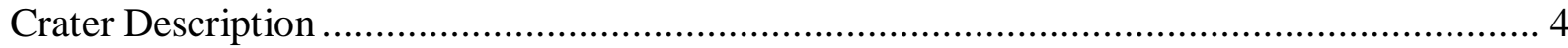

Surface Water Modeling Approach.......................................................................... 4

Vadose Zone Modeling Approach ........................................................................................ 6

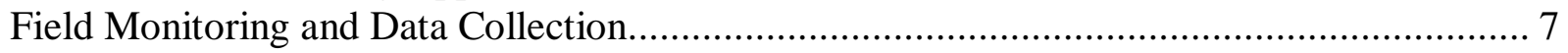

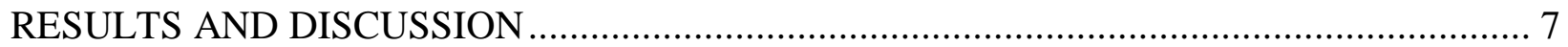

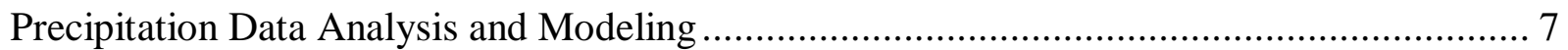

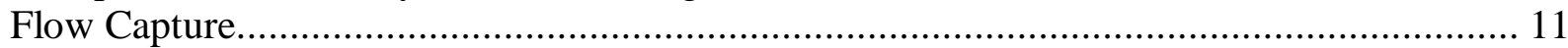

Tributary Basin Delineation and Flow Capture ................................................................ 11

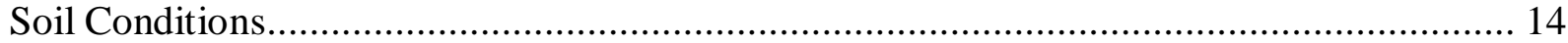

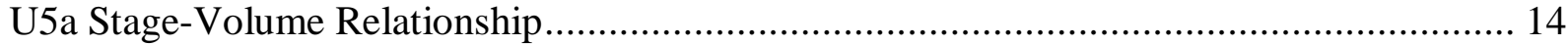

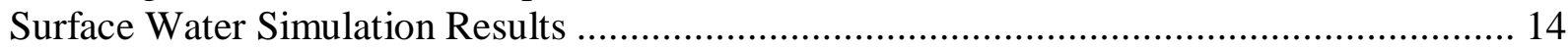

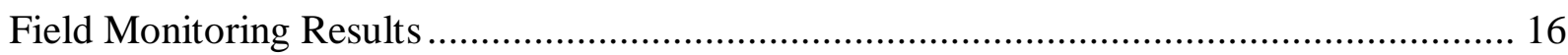

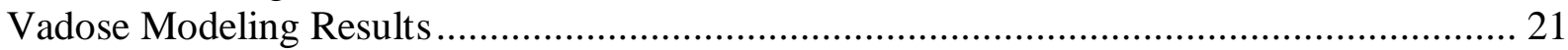

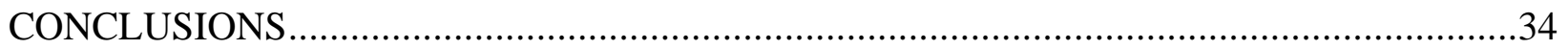

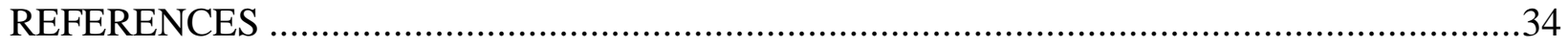




\section{FIGURES}

1. Location of crater U5a on the Nevada Test Site, Nye County, Nevada ...........................5

2. Barren Wash drainage area depicted in relation to crater U5a and its smaller drainage area

3. Crater U5a has captured a well-defined, smaller drainage area within the larger Barren Wash drainage area shown in the previous figure

4. Plots of air temperature and wind speeds recorded at crater U5a

5. Maximum precipitation recorded per 15-minute interval and daily totals .18

6. Detailed views of the two small ponding events recorded at crater U5a.....

7. Soil moisture profiles measured with the neutron moisture meter for wells U5a-n1 and n2

8. U5a material distribution used for vadose zone modeling

9. Moisture profiles predicted from surface and vadose zone modeling during the first 14 years of the crater's existence.

10. Moisture profiles predicted from surface and vadose zone modeling for years 15 through 20 .

11. Moisture profiles predicted from surface and vadose zone modeling for years 20 through 27 .

12. Moisture profiles predicted from surface and vadose zone modeling for years 28 through 32 .

13. Change in moisture storage (upper plot) and wetting front advancement resulting from simulated ponding events in crater U5a

14. A $400-\mathrm{m}^{3}$ ponding event followed by $\sim 6$ years of moisture redistribution was modeled using three different sets of soil properties 


\section{TABLES}

1. Summary of precipitation data on Frenchman Flat on the Nevada Test Site at station well 5B

2. Correlation coefficients as a measure of the goodness-of-fit description of the expected number of days of precipitation per month by a normal distribution at station well 5B

3. Correlation coefficients as a measure of the goodness-of-fit description of the expected depth of precipitation per day of precipitation by a normal distribution for station well 5B.

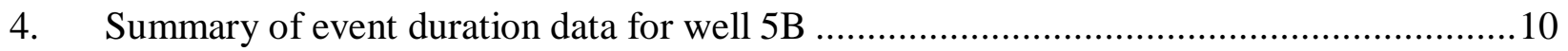

5. Simulation of water capture over a 32-year period at crater U5a using three different AMC CN Scenarios

6. Van Genuchten parameters for U5a report and Levitt and Sully (1998).....

7. The volume of ponding events and their timing as predicted by the surface water modeling 


\section{INTRODUCTION}

Radionuclides are present both below and above the water table at the Nevada Test Site (NTS), as the result of underground nuclear testing. Mobilization and transport of radionuclides from the vadose zone is a complex process that is influenced by the solubility and sorption characteristics of the individual radionuclides, as well as the soil water flux rate. Recent work in Area 5, based on environmental tracers, suggests that present-day groundwater recharge is not occurring and that recharge conditions have not existed at Frenchman Flat since pluvial conditions, which are thought to have existed during the last full glacial maxima, approximately 20,000 to 120,000 years before present (BP) (Tyler et al., 1996). During this period, a recharge rate of approximately $7 \mathrm{~mm}$ per year was estimated for this area. Recharge had not occurred in over 100,000 years BP within most of the study area; however, some areas had evidence of recharge conditions at 20,000 years BP. Tyler et al. (1996) attributed this difference to geomorphic positioning, since the areas with more recent recharge were near a very minor ephemeral channel.

On the NTS, subsidence craters resulting from underground nuclear testing are numerous and many intercept surface water flows. Water ponded several meters deep has been observed in craters following precipitation events (D. Duncan, 1997, U.S. Department of Energy, pers. comm.), and active headward erosion is taking place at some craters. Owing to craters collecting surface water above the sub-surface point of device detonation, these craters may provide a mechanism for surface water to recharge the groundwater aquifer underlying the NTS. Given this situation, there is a potential for the captured water to introduce contaminants into the groundwater system.

Such enhanced recharge rates have been documented at crater U3fd in Yucca Flat. At U3fd, soil water tritium and traditional soil physics approaches were used to determine a recharge rate of $60 \mathrm{~cm} /$ year (Tyler et al., 1992), whereas recharge rates outside the crater environment were nearly zero. Comparison of the current recharge rates for inside the crater calculated at U3fd to the estimated paleoclimate recharge rates reveals the importance of geomorphic and geographic setting to recharge rates ( $7 \mathrm{~mm}$ vs. $600 \mathrm{~mm}$ per year).

Bechtel Nevada has conducted extensive investigations characterizing subsidence craters within the Radioactive Waste Management Site (RWMS) at Area 3 of the NTS (Bechtel Nevada, 1998). The purpose of these studies was to provide physical and hydraulic properties and other hydrologic information required to develop a conceptual hydrologic model and conduct flow and transport modeling. Craters in three different stages were investigated: 1) waste-filled craters with a temporary soil cover in place; 2) active waste storage craters partially filled with waste; and 3) craters with no waste in them. Boreholes were drilled beneath each type of crater to assess hydrologic conditions in the "collapse zones" of the crater environment. These data were compared to soil samples collected from boreholes outside of the crater environment. The 
general conclusion was that the hydraulic properties of the soils within the collapse zone were not distinguishable from the non-disturbed soil outside the collapse zones. From this it was concluded that the collapse zone of craters did not create a preferential flowpath for moisture. Beneath all types of craters studied, moisture conditions within the upper 50 to $80 \mathrm{~m}$ of soil were elevated when compared to soil moisture in the non-crater regions. However, based on hydraulic gradient data and moisture redistribution modeling, it was determined that the moisture encountered was relatively immobile, moving at such a slow velocity that travel times to the water table would not be within the operational life span of the facility. At greater depths, 120 to $140 \mathrm{~m}$, elevated moisture conditions were encountered, but stable isotopic data indicated that this soil moisture had infiltrated during a much wetter, cooler climate. The possibility of runoff waters reaching the craters in the Area 3 RWMS is greatly reduced by the flood control structures that divert water around the facility. The study does, however, suggest that should additional inputs of surface water occur, this moisture could move at higher rates.

The consequences of subsidence and subsequent flooding were investigated for the U-3ah/at waste cell within the Area 3 RWMS. Flood water volumes were calculated using the U.S. Army Corps of Engineers rainfall-runoff model for the 100-year flood event. The development of a flood volume-frequency relationship was determined by plotting the derived volumes against the return periods (probability or frequency) on log-probability paper, allowing extrapolation of the 200-, 500-, and 1,000-year flood events. Stage volume relationships were developed for each flood volume, indicating that the depth of ponding in U-3ah/at would be 2, 2.5, 3.2, and $4 \mathrm{~m}$, respectively, for the 100-, 200-, 500-, and 1,000-year flood events (G.J. Shott, 1998, Bechtel Nevada, pers. comm.). To simulate the result of a worst-case scenario flood event in a fully subsided waste cell, the 1,000-year flood event was simulated for U-3ah/at using the VS2DT computer code, which solves the Richards equation for variably saturated flow in a porous media. A single 1,000-year flood event resulted in the introduction of 49,300 $\mathrm{m}^{3}$ of water with a depth of $4 \mathrm{~m}$ in the crater bottom. Modeling results indicated that during the first 50 years, the wetting front reached approximately $150 \mathrm{~m}$ and reached the water table in approximately 950 years. The resulting steady-state recharge rate was approximately $3.6 \mathrm{~mm} / \mathrm{year}$, which lasted for approximately 150 years (G.J. Shott, 1998, Bechtel Nevada, pers. comm.).

Vadose zone modeling performed by Bechtel Nevada also considered the consequences of subsidence at the Area 5 RWMS within Pit 5, followed by extreme flooding, resulting in $2 \mathrm{~m}$ of ponded water. This flooding condition was repeated for three consecutive years and then no additional flooding was simulated. The moisture redistribution was modeled until it reached the water table (Crowe et al., 1998). Within the first three years, while flooding inputs were simulated, the wetting front advanced to approximately $75 \mathrm{~m}$. Following the simulated flood events, the wetting front advancement slowed dramatically, requiring 190 years to reach the water table. Conditions were also considered where the waste material was at varying degrees of moisture content. It was concluded that even in the worst-case scenarios where the waste is saturated, there is little impact on water movement and travel times to the water table, and 
therefore little impact on transport of radionuclides in the vadose zone from the introduction of excessive moisture in the waste (Crowe et al., 1998).

At the Area 3 RWMS, the redistribution of moisture conditions found beneath the craters was modeled by Bechtel Nevada. Modeling was conducted using horizontally layered soils and non-layered soils. In the case of layered soils, the moisture was shown to be practically immobile, though it was noted that wetting front advancement would begin should future inputs of ponding be encountered (Bechtel Nevada, 1998). This was compared to modeling where a homogeneous, non-layered soil was used. In the non-layered system, the wetting front advanced approximately $20 \mathrm{~m}$ in 100 years. A later time step was not shown, but presumably the next 100 years would yield only limited redistribution without additional inputs of surface ponding. The results of both the layered and non-layered soils are in general agreement with vadose zone modeling at U5a; elevated moisture in the vadose zone is relatively immobile without inputs from surface water ponding.

The objective of the current project was to select and study a subsidence crater within the Frenchman Flat Basin with higher than normal recharge potential, as compared to other craters. The criteria used to rank crater recharge potential were: size, number and extent of erosion features; size of potential drainage area; formation of depositional features within the craters such as small playas, depositional fans, and depositional shelves associated with sediment encountering standing water; and phreataphytic vegetation. Using these criteria, crater U5a clearly had the highest potential for recharge within Frenchman Flat. It was beyond the scope of this project to compare crater U5a to Yucca Flat craters, though it appears to have higher recharge potential than the average Yucca Flat crater. Owing to U5a having higher recharge potential than any other crater in Frenchman Flat and probably higher recharge potential than the average Yucca Flat crater, the results presented here represent recharge potential in a high recharge potential subsidence crater.

In 1996, preliminary work at crater U5a in Frenchman Flat suggested that potential recharge conditions were elevated over the background recharge rates, evidenced by moist soil conditions and downward gradients for moisture movement. The bottom of this subsidence crater was covered by playa deposits exhibiting a very low hydraulic conductivity. Vadose zone modeling indicated that during ponding events, water could quickly percolate through the coarse sand surrounding the playa bottom at U5a, thus allowing a high percentage of the impounded water to escape to depths beyond the reach of evapotranspiration (Hokett and Gillespie, 1996). However, in 1996, analysis of surface water flow had not yet been performed to estimate the volume of water that may have contributed to the crater over its life span. The objective of this study was to combine surface water and vadose zone modeling to estimate recharge rates in crater U5a. 


\section{MATERIALS AND METHODS}

\section{Crater Description}

Crater U5a is located in Area 5 of the NTS just north of the Frenchman Flat Playa (Figure 1). It is the result of a Lawrence Livermore National Laboratory underground nuclear test (WISHBONE) conducted on February 18, 1965, at a depth of $174.9 \mathrm{~m}$ below land surface. The static water level at this point is estimated to be $206 \mathrm{~m}$ below land surface. Surveying immediately following cratering indicated that the crater had a diameter of approximately $40 \mathrm{~m}$ with a depth of $27.4 \mathrm{~m}$.

At the beginning of this study, a topographic survey was conducted by Bechtel Nevada to determine the ground zero location, which is now covered with sediment, and to determine the current depth and topography of the crater. The survey indicated that the current low spot (now defined by a playa) is no longer in the center of the crater. Deposition of sediments in the crater bottom, originating from the north, has resulted in the current playa position being pushed to the southern edge of the crater. The playa is well defined, elliptical in shape, and comprises a $330 \mathrm{~m}^{2}$ area. Current depth of the crater is now $12.8 \mathrm{~m}$, representing a maximum infilling of $14.6 \mathrm{~m}$ over the last 30 years (Hokett and Gillespie, 1996).

Large erosional gullies are evident all along the north edges of the crater. Some of these gullies are approximately $5 \mathrm{~m}$ deep. Large stands of salt cedar appear to grow in rings around the current playa location at the southern end of the crater and around previous playa locations further to the north.

\section{Surface Water Modeling Approach}

There are few data regarding surface or overland flow events on the NTS. However, precipitation data are collected at a number of locations and some gages have a relatively long period of record (French, 1989). For example, in the vicinity of Frenchman Flat (Figure 1), there is a nearby precipitation gage having 33 years of continuous record. While these records likely do not contain extreme events such as the 100- and 500-year storms, from the viewpoint of groundwater recharge, such extreme events are likely less important than more frequent events (see for example, French et al., 1996 or Lane and Osterkamp, 1991). Therefore, it was decided that these precipitation records would be used as the basis of estimating runoff from watershed tributaries to the craters of interest.

From the groundwater recharge perspective, the runoff hydrograph is not as important as the volume of precipitation delivered to a potential recharge area, in this case, the detonation crater. Direct runoff from a precipitation event was estimated using the Soil Conservation Service (SCS) curve number approach. By definition, the curve number is

$$
C N=\frac{1000}{S+10}
$$




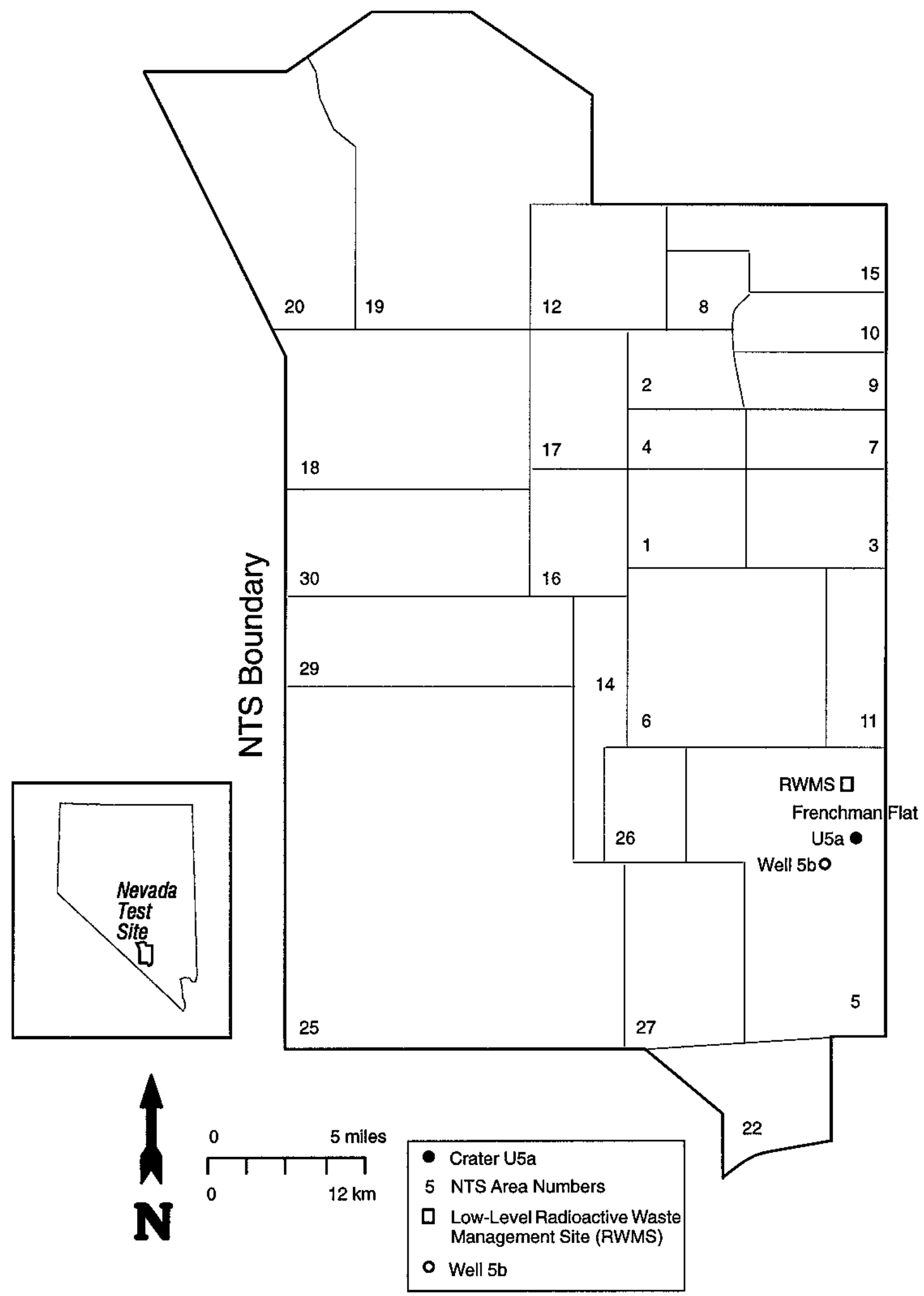

Figure 1. Location of crater U5a on the Nevada Test Site, Nye County, Nevada. 
where $\mathrm{CN}=\mathrm{SCS}$ curve number and $\mathrm{S}=$ maximum moisture retention during and leading up to a runoff event. Rearranging

$$
S=\frac{1000}{C N}-10
$$

The initial abstraction of precipitation is defined as the volume of moisture that the soil retains prior to the onset of runoff. Assuming that the initial abstraction of precipitation is 20 percent of the maximum retention, the relationship between the depths of precipitation $(\mathrm{P})$ and runoff $(\mathrm{Q})$ is

$$
Q=\frac{(P-0.2 S)^{2}}{(P+0.8 S)}
$$

or

$$
Q=\frac{\left[P-\frac{200}{C N}-2\right]^{2}}{P+\frac{800}{C N}-8}
$$

Although other methods of estimating direct runoff are available, relative to the quality and quantity of data available, the curve number approach is reasonable in this application. It is important to recognize that the curve number of the watershed may change not only in response to the antecedent moisture condition but also because the soil may be frozen, though in Frenchman Flat frozen soil is rare (M. Sully, 1997, Bechtel Nevada, pers. comm.).

Careful consideration must be given to the areal extent of the watersheds potentially tributary to the crater or water harvest basin. In the case of a basin designed and located to harvest flood waters, the tributary watershed is likely better defined than in the case of a detonation crater. In contrast, the detonation craters on the NTS are, in most cases, not located in the bottom of well-defined channels, and in many cases, the tributary watersheds to detonation craters appear to be the result of capture; that is, precipitation falling directly on the crater walls aided by inflow from a very limited surrounding area initiates headward erosion, which progresses and captures an ever-increasing watershed area. In addition to the local, directly tributary watershed, the potential contribution of the much larger upstream watershed must also be considered.

\section{Vadose Zone Modeling Approach}

Vadose zone modeling was conducted using the HYDRUS2D finite element numerical model developed by Simunek and van Genuchten (1996). The program numerically solves Richards equation for saturated-unsaturated water flow and the convection-dispersion equation for solute transport. The flow equation incorporates a sink term to account for water uptake by plant roots. The program may be used to analyze water and solute movement in unsaturated or 
variably saturated porous media. HYDRUS2D can handle flow domains delineated by irregular boundaries. The flow region itself may be composed of non-uniform soils having an arbitrary degree of local anisotropy. Flow and transport can occur in the vertical plane, the horizontal plane, or in a two-dimensional region exhibiting radial symmetry about a vertical axis. The water flow portion of the model considers prescribed head, hydraulic gradient, and flux boundaries.

\section{Field Monitoring and Data Collection}

In 1996, field equipment was installed at crater U5a to measure and record precipitation, relative humidity, water depth during ponding events, air temperature, wind speed, and wind direction. Additionally, soil moisture with depth was monitored periodically using a neutron moisture meter.

\section{RESULTS AND DISCUSSION}

\section{Precipitation Data Analysis and Modeling}

Precipitation data for the well 5B station, in the vicinity of Frenchman Lake, are summarized in Table 1. The annual average depth of precipitation at well $5 \mathrm{~B}$ is $12.6 \mathrm{~cm}$. In both the case of annual average depth of precipitation and monthly average depth of precipitation, the associated standard deviations are of the same order of magnitude as the averages, and in some cases, larger. This observation has been previously discussed (French, 1989; 1987), and the conclusion is that precipitation is highly variable in southern Nevada. With exceptions, the monthly average depths of precipitation are slightly greater during the winter period than the summer period. In southern Nevada, the winter period is generally October through April, inclusive. Further, snow and frozen soil are uncommon in the vicinity of Frenchman Lake. The available gaging records only provide data regarding the depth of precipitation and do not differentiate between snow and rain.

It was hypothesized that the number of days of precipitation in a specified month can be described by a normal probability distribution. The average number of days of precipitation, the standard deviation, and the correlation coefficients between the number of days of precipitation per month and the normal distribution are summarized in Table 2 for the well 5B station. The high values of the correlation coefficients (Column 4) support the hypothesis. It was also hypothesized that the depth of precipitation per day of precipitation in a specified month can be described by a normal probability distribution. The average depth of precipitation per day of precipitation, the standard deviation and the correlation coefficients between the depth of precipitation per day of precipitation and the normal distribution are summarized in Table 3 for the well 5B station. The high values of these correlation coefficients (Column 4) support the hypothesis. 
Table 1. Summary of Precipitation Data on Frenchman Flat on the Nevada Test Site at Station Well 5B.

\begin{tabular}{lcc}
\hline Month & Average Depth of Precipitation $(\mathrm{cm})$ & Standard Deviation $(\mathrm{cm})$ \\
\hline January & 1.73 & 1.70 \\
February & 1.45 & 1.93 \\
March & 1.52 & 1.65 \\
April & 0.76 & 0.99 \\
May & 0.79 & 1.02 \\
June & 0.30 & 0.53 \\
July & 1.07 & 1.40 \\
August & 1.37 & 1.98 \\
September & 0.74 & 0.99 \\
October & 0.61 & 0.79 \\
November & 0.99 & 1.09 \\
December & 1.30 & 1.55 \\
Annual & 12.65 & 5.21 \\
\hline
\end{tabular}

Table 2. Correlation Coefficients as a Measure of the Goodness-of-Fit Description of the Expected Number of Days of Precipitation Per Month by a Normal Distribution at Station Well 5B.

\begin{tabular}{lccc}
\hline Month & Days of Precipitation & Standard Deviation & Correlation Coefficient \\
\hline January & 4.0 & 3.6 & 0.96 \\
February & 3.5 & 3.0 & 0.99 \\
March & 4.2 & 3.3 & 0.99 \\
April & 2.8 & 2.3 & 0.98 \\
May & 2.3 & 1.7 & 1.00 \\
June & 1.3 & 1.5 & 0.96 \\
July & 2.5 & 1.8 & 0.99 \\
August & 2.8 & 2.3 & 0.99 \\
September & 1.8 & 1.8 & 0.98 \\
October & 1.8 & 1.8 & 0.93 \\
November & 2.7 & 2.4 & 0.98 \\
December & 3.1 & 2.7 & 0.97 \\
\hline
\end{tabular}


Table 3. Correlation Coefficients as a Measure of the Goodness-of-Fit Description of the Expected Depth of Precipitation Per Day of Precipitation by a Normal Distribution for Station Well 5B.

\begin{tabular}{lccc}
\hline Month & Depth of Precipitation $(\mathrm{cm})$ & Standard Deviation $(\mathrm{cm})$ & Correlation Coefficient \\
\hline January & 0.330 & 0.279 & 0.97 \\
February & 0.254 & 0.229 & 0.98 \\
March & 0.254 & 0.203 & 0.98 \\
April & 0.203 & 0.203 & 0.94 \\
May & 0.254 & 0.254 & 0.95 \\
June & 0.127 & 0.152 & 0.95 \\
July & 0.305 & 0.305 & 0.94 \\
August & 0.356 & 0.406 & 0.92 \\
September & 0.305 & 0.381 & 0.92 \\
October & 0.279 & 0.508 & 0.69 \\
November & 0.305 & 0.381 & 0.90 \\
December & 0.330 & 0.330 & 0.96 \\
\hline
\end{tabular}

Precipitation event duration data for the well 5B station over the period of record are summarized in Table 4. In this discussion, an event duration is defined as the number of consecutive days of precipitation. For example, if there was one day of precipitation with no precipitation on either the day before or the day after, then the event had a duration of one day. Also, if there was precipitation on two consecutive days, then this was also one event with a twoday duration. Data in Table 4 led to the following observations. In all months, except October, one-day-duration events are more than 50 percent of all events. During the summer period (May - September, inclusive), one-day-duration events are likely convective storm events with short durations and high intensities. This is supported by a detailed analysis of the precipitation data at well 5B for the period 1963-1979, which showed that 68 percent of all events at this location were two hours or less in duration and that 66 percent of all events during the summer period were four hours or less in duration (French, 1983). Events two days or more in duration can occur during any month but are particularly frequent during the winter period when multiple-day durations are likely the result of frontal systems with long durations and low intensities. Events with durations greater than five days are generally rare and do not occur during the summer period. 
Table 4. Summary of Event Duration Data for Well 5B. (Number of events by month; fraction of all events; cumulative distribution.)

\begin{tabular}{|c|c|c|c|c|c|c|c|c|c|c|c|c|}
\hline $\begin{array}{c}\text { Duration } \\
\text { (days) }\end{array}$ & Jan & $\mathrm{Feb}$ & Mar & Apr & May & June & July & Aug & Sept & Oct & Nov & Dec \\
\hline 1 & $\begin{array}{l}37 \\
(0.51)\end{array}$ & $\begin{array}{l}36 \\
(0.57)\end{array}$ & $\begin{array}{l}46 \\
(0.55)\end{array}$ & $\begin{array}{l}51 \\
(0.76)\end{array}$ & $\begin{array}{l}27 \\
(0.55)\end{array}$ & $\begin{array}{l}26 \\
(0.81)\end{array}$ & $\begin{array}{l}36 \\
(0.67)\end{array}$ & $\begin{array}{l}38 \\
(0.64)\end{array}$ & $\begin{array}{l}31 \\
(0.72)\end{array}$ & $\begin{array}{l}31 \\
(0.69)\end{array}$ & $\begin{array}{l}35 \\
(0.39)\end{array}$ & $\begin{array}{l}42 \\
(0.65)\end{array}$ \\
\hline & & & & & & & & & & (0.69) & & \\
\hline 2 & $\begin{array}{l}21 \\
(0.29)\end{array}$ & $\begin{array}{l}14 \\
(0.22)\end{array}$ & $\begin{array}{l}28 \\
(0.33)\end{array}$ & $\begin{array}{l}9 \\
(0.13)\end{array}$ & $\begin{array}{l}17 \\
(0.35)\end{array}$ & $\begin{array}{l}3 \\
(0.09)\end{array}$ & $\begin{array}{l}12 \\
(0.22)\end{array}$ & $\begin{array}{l}14 \\
(0.24)\end{array}$ & $\begin{array}{l}8 \\
(0.19)\end{array}$ & $\begin{array}{l}12 \\
(0.27)\end{array}$ & $\begin{array}{l}16 \\
(0.36)\end{array}$ & $\begin{array}{l}16 \\
(0.25)\end{array}$ \\
\hline & $(0.80)$ & $(0.79)$ & $(0.88)$ & $(0.89)$ & (0.90) & $(0.90)$ & $(0.89)$ & $(0.88)$ & $(0.91)$ & $(0.96)$ & $(0.75)$ & $(0.90)$ \\
\hline 3 & $\begin{array}{l}7 \\
(0.10)\end{array}$ & $\begin{array}{l}6 \\
(0.10)\end{array}$ & $\begin{array}{l}6 \\
(0.07)\end{array}$ & $\begin{array}{l}6 \\
(0.09)\end{array}$ & $\begin{array}{l}5 \\
(0.10)\end{array}$ & $\begin{array}{l}2 \\
(0.06)\end{array}$ & $\begin{array}{l}4 \\
(0.07)\end{array}$ & $\begin{array}{l}3 \\
(0.05)\end{array}$ & $\begin{array}{l}3 \\
(0.07)\end{array}$ & $\begin{array}{l}2 \\
(0.04)\end{array}$ & & $\begin{array}{l}3 \\
(0.05)\end{array}$ \\
\hline & $(0.90)$ & (0.89) & $(0.95)$ & (0.98) & (1.0) & $(0.96)$ & $(0.96)$ & $(0.93)$ & $(0.98)$ & (1.0) & $(0.75)$ & $(0.95)$ \\
\hline 4 & $\begin{array}{l}5 \\
(0.07)\end{array}$ & $\begin{array}{l}4 \\
(0.06)\end{array}$ & $\begin{array}{l}2 \\
(0.02)\end{array}$ & $\begin{array}{l}1 \\
(0.01)\end{array}$ & & $\begin{array}{l}1 \\
(0.03)\end{array}$ & $\begin{array}{l}1 \\
(0.02)\end{array}$ & $\begin{array}{l}4 \\
(0.07)\end{array}$ & $\begin{array}{l}0 \\
(0)\end{array}$ & $\begin{array}{l}0 \\
(0)\end{array}$ & $\begin{array}{l}3 \\
(0.13)\end{array}$ & $\begin{array}{l}1 \\
(0.01)\end{array}$ \\
\hline & $(0.97)$ & $(0.95)$ & $(0.97)$ & (0.99) & (1.0) & (0.99) & $(0.98)$ & $(1.0)$ & $(0.98)$ & (1.0) & $(0.88)$ & $(0.96)$ \\
\hline 5 & $\begin{array}{l}1 \\
(0.01)\end{array}$ & $\begin{array}{l}1 \\
(0.02)\end{array}$ & $\begin{array}{l}2 \\
(0.02)\end{array}$ & $\begin{array}{l}0 \\
(0)\end{array}$ & $\begin{array}{l}0 \\
(0)\end{array}$ & & $\begin{array}{l}1 \\
(0.02)\end{array}$ & $\begin{array}{l}0 \\
(0)\end{array}$ & $\begin{array}{l}1 \\
(0.02)\end{array}$ & $\begin{array}{l}0 \\
(0)\end{array}$ & $\begin{array}{l}2 \\
(0.12)\end{array}$ & $\begin{array}{l}2 \\
(0.03)\end{array}$ \\
\hline & (0.98) & $(0.97)$ & (0.99) & (0.99) & (1.0) & (0.99) & $(1.0)$ & (1.0) & $(1.0)$ & (1.0) & (1.0) & $(0.99)$ \\
\hline 6 & $\begin{array}{l}0 \\
(0) \\
(0.98)\end{array}$ & $\begin{array}{l}1 \\
(0.02) \\
(0.99)\end{array}$ & $\begin{array}{l}0 \\
(0) \\
(0.99)\end{array}$ & $\begin{array}{l}0 \\
(0) \\
(0.99)\end{array}$ & $\begin{array}{l}0 \\
(0) \\
(1.0)\end{array}$ & $\begin{array}{l}0 \\
(0) \\
(0.99)\end{array}$ & $\begin{array}{l}0 \\
(0) \\
(1.0)\end{array}$ & $\begin{array}{l}0 \\
(0) \\
(1.0)\end{array}$ & $\begin{array}{l}0 \\
(0) \\
(1.0)\end{array}$ & $\begin{array}{l}0 \\
(0) \\
(1.0)\end{array}$ & $\begin{array}{l}0 \\
(0) \\
(1.0)\end{array}$ & $\begin{array}{l}1 \\
(0.01) \\
(1.0)\end{array}$ \\
\hline 7 & $\begin{array}{l}1 \\
(0.01) \\
(0.99)\end{array}$ & $\begin{array}{l}1 \\
(1.01) \\
(1.0)\end{array}$ & $\begin{array}{l}0 \\
(0) \\
(0.99)\end{array}$ & $\begin{array}{l}0 \\
(0) \\
(0.99)\end{array}$ & $\begin{array}{l}0 \\
(0) \\
(1.0)\end{array}$ & $\begin{array}{l}0 \\
(0) \\
(0.99)\end{array}$ & $\begin{array}{l}0 \\
(0) \\
(1.0)\end{array}$ & $\begin{array}{l}0 \\
(0) \\
(1.0)\end{array}$ & $\begin{array}{l}0 \\
(0) \\
(1.0)\end{array}$ & $\begin{array}{l}0 \\
(0) \\
(1.0)\end{array}$ & $\begin{array}{l}0 \\
(0) \\
(1.0)\end{array}$ & $\begin{array}{l}0 \\
(0) \\
(1.0)\end{array}$ \\
\hline 8 & $\begin{array}{l}0 \\
(0) \\
(0.99)\end{array}$ & $\begin{array}{l}0 \\
(0) \\
(1.01)\end{array}$ & $\begin{array}{l}0 \\
(0) \\
(0.99)\end{array}$ & $\begin{array}{l}0 \\
(0) \\
(0.99)\end{array}$ & $\begin{array}{l}0 \\
(0) \\
(1.0)\end{array}$ & $\begin{array}{l}0 \\
(0) \\
(0.99)\end{array}$ & $\begin{array}{l}0 \\
(0) \\
(1.0)\end{array}$ & $\begin{array}{l}0 \\
(0) \\
(1.0)\end{array}$ & $\begin{array}{l}0 \\
(0) \\
(1.0)\end{array}$ & $\begin{array}{l}0 \\
(0) \\
(1.0)\end{array}$ & $\begin{array}{l}0 \\
(0) \\
(1.0)\end{array}$ & $\begin{array}{l}0 \\
(0) \\
(1.0)\end{array}$ \\
\hline 9 & $\begin{array}{l}0 \\
(0) \\
(0.99)\end{array}$ & $\begin{array}{l}0 \\
(0) \\
(1.01)\end{array}$ & $\begin{array}{l}0 \\
(0) \\
(0.99)\end{array}$ & $\begin{array}{l}0 \\
(0) \\
(0.99)\end{array}$ & $\begin{array}{l}0 \\
(0) \\
(1.0)\end{array}$ & $\begin{array}{l}0 \\
(0) \\
(0.99)\end{array}$ & $\begin{array}{l}0 \\
(0) \\
(1.0)\end{array}$ & $\begin{array}{l}0 \\
(0) \\
(1.0)\end{array}$ & $\begin{array}{l}0 \\
(0) \\
(1.0)\end{array}$ & $\begin{array}{l}0 \\
(0) \\
(1.0)\end{array}$ & $\begin{array}{l}0 \\
(0) \\
(1.0)\end{array}$ & $\begin{array}{l}0 \\
(0) \\
(1.0)\end{array}$ \\
\hline $\begin{array}{l}\text { Total } \\
\text { (events) }\end{array}$ & 72 & 63 & 84 & 67 & 49 & 32 & 54 & 59 & 43 & 45 & 56 & 65 \\
\hline
\end{tabular}

Based on these observations and hypotheses, a stochastic precipitation simulation model was developed for use in the surface water ponding predictions. In this model, the user specifies the number of years to be simulated. For each month in the simulation period, a normally distributed random number (Press et al., 1986) on the interval [0,1] is selected, and the number of days of precipitation is estimated by

$$
(\text { days })_{i}=\mu_{n i}+R \sigma_{n i}
$$

where $($ days $)=$ number of days of precipitation in month $i ; \mu_{\mathrm{ni}}=$ mean number of days of precipitation in month $I ; \sigma_{v l}=$ standard deviation of the number of days of precipitation in month $i$; and $\mathrm{R}$ is a normally distributed random number. A normally distributed random number is selected for each day of precipitation in a month to estimate the depth of precipitation by

$$
(\text { depth })_{i, j}=\mu_{d, i}+R \sigma_{d, i}
$$

where $($ depth $)=$ depth of precipitation for month $i$ and day of precipitation $j$ in that month; $\mu_{\mathrm{d}, \mathrm{i}}=$ mean depth of precipitation per day of precipitation in month $I$; and $\sigma_{\mathrm{d}, \mathrm{i}}=$ standard deviation of the depth of precipitation per day of precipitation in month $i$. The days of precipitation during a month are then combined into multiple days of precipitation by selecting a random number 
uniformly distributed on the interval $[0,1]$ and then using the empirical duration distributions defined in Table 4.

\section{Flow Capture}

The volume of water captured by a crater is estimated by one of three methods. The first method assumes all of the flow from the upstream watershed flows to the crater. The second method is a probabilistic approach similar to that described by Dawdy (1979) for estimating flood hazard on alluvial fans; that is, the probability of a flow being captured is proportional to the ratio of the width of the crater projected onto the contour passing though it to the width of the watershed contour and a choice is made on the basis of a random number uniformly distributed on the interval $[0,1]$ or

$$
\begin{aligned}
& \text { If } 0 \leq R \leq \frac{W_{c}}{W_{w}} \text { flow into the crater } \\
& \text { if } \frac{W_{c}}{W_{w}}<R \leq 1 \text { flow misses the crater }
\end{aligned}
$$

where $\mathrm{W}_{\mathrm{c}}=$ crater width projected onto the watershed contour width; $\mathrm{W}_{\mathrm{w}}=$ watershed contour width; and $\mathrm{R}=$ a random number. This method is likely more applicable to infrequent flood flows than it is to the more frequent events hypothesized to be important to groundwater recharge. The third method assumes that the flow occurs as sheetflow; therefore, the volume of water intercepted by the crater is proportional to the ratio of the crater width projected onto the watershed contour

$$
Q_{c}=\left[\frac{\left(P-\frac{200}{C N}-2\right)^{2}}{P+\frac{800}{C N}-8}\right]\left[\frac{W_{c}}{W_{w}}\right]
$$

where $\mathrm{Q}_{\mathrm{c}}=$ direct runoff (in) captured by the crater and all other variables are as previously defined.

\section{Tributary Basin Delineation and Flow Capture}

The U5a crater is located near Frenchman Lake approximately 2,591 m northeast of the well 5B precipitation gage (Figure 1). Previous investigations have established that this crater is located on the Barren Wash alluvial fan (Schmeltzer et al., 1993). The upstream watershed potentially tributary to this crater has an area of approximately $210 \mathrm{~km}^{2}$, but the flowpath from the top of watershed to the crater is poorly defined and crosses multiple and extensive areas of anthropogenic disturbance and non-cohesive and highly permeable soils. It is likely that the complete Barren Wash watershed contributes flows to U5a only very infrequently, therefore, it is 
ignored. The apex and boundaries of the Barren Wash alluvial fan are shown in Figure 2 (Schmeltzer et al., 1993). The area of the Barren Wash alluvial fan is $14.5 \mathrm{~km}^{2}$. In the vicinity of U5a, there are two incised channels linking the crater to the upstream watershed (Figure 3). Approximately $180 \mathrm{~m}$ upstream of U5a these channels are no longer incised but sufficiently defined to easily identify them in the field. The watershed associated with these channels is approximately $0.65 \mathrm{~km}^{2}$. The watershed was defined to include the crater since there are a number of incised channels that collect and channel the water to the crater all around its perimeter. It is likely that the watershed that contributes flow to the crater is greater than $0.65 \mathrm{~km}^{2}$; therefore, the estimated harvest of water will be low. The roads shown in Figure 3 may introduce water from other watersheds into the system.

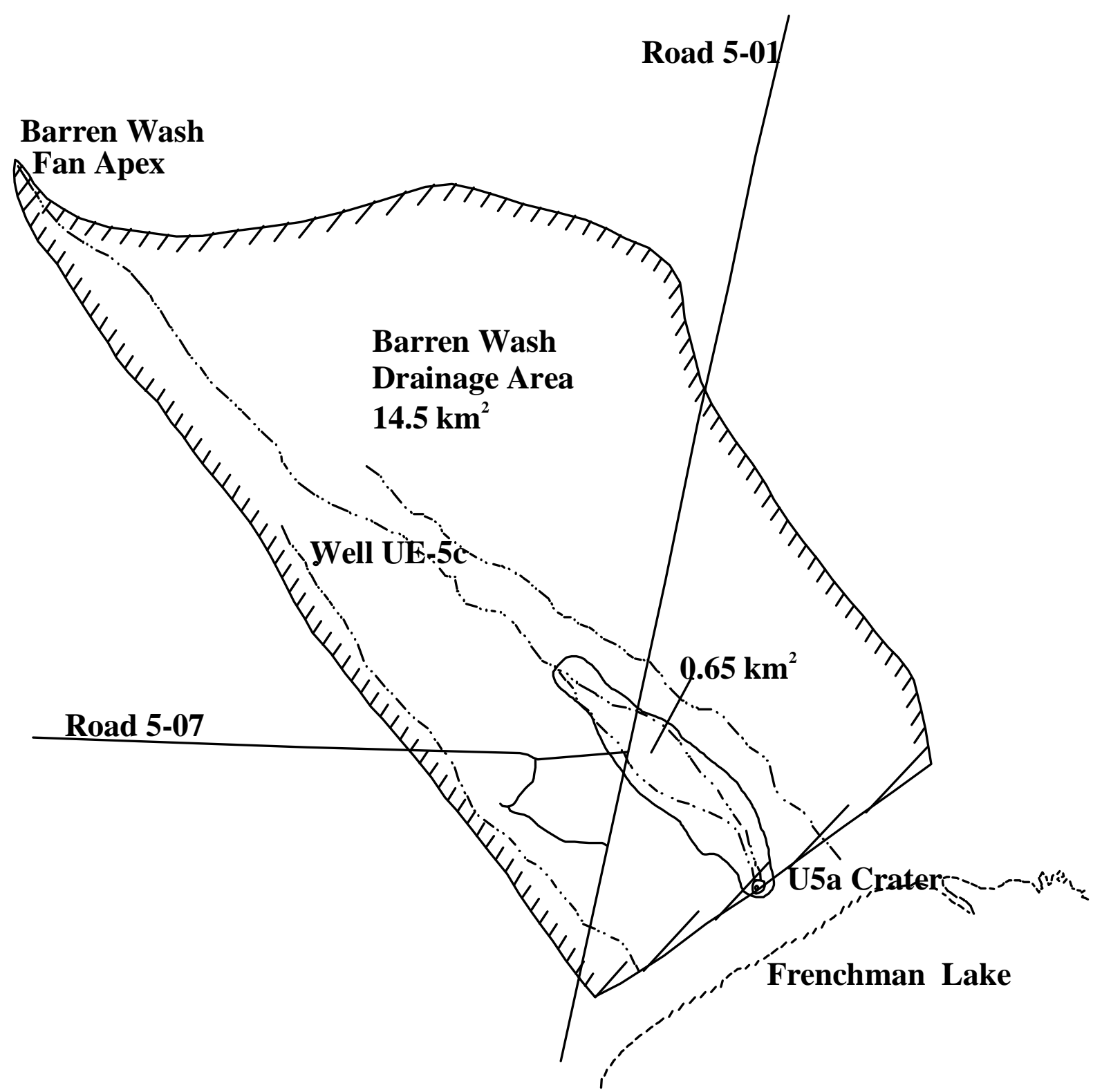

Figure 2. Barren Wash drainage area depicted in relation to crater U5a and its smaller drainage area. 


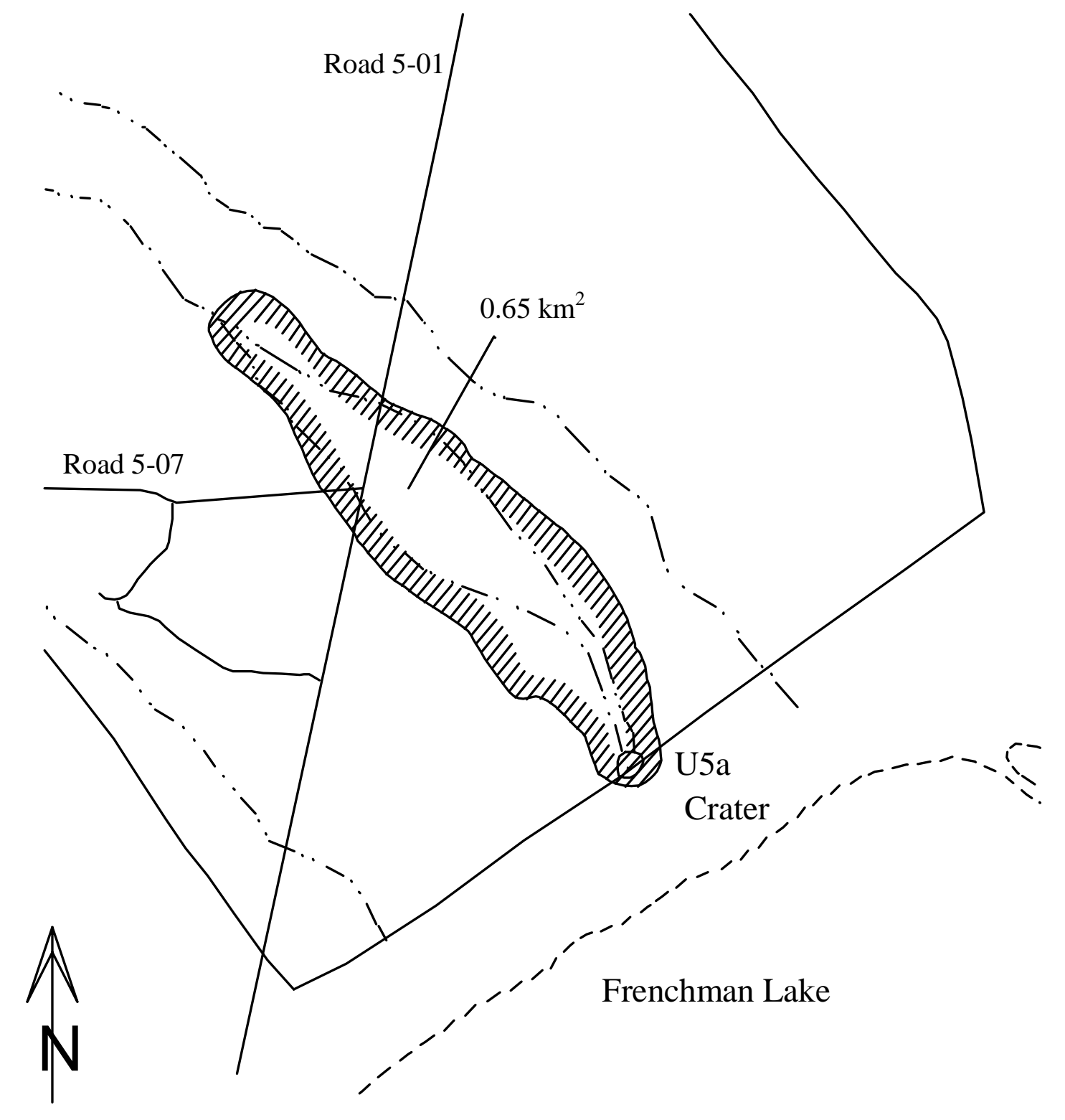

Figure 3. Crater U5a has captured a well-defined, smaller drainage area within the larger Barren Wash drainage area shown in the previous figure.

It was originally intended to study two flow capture scenarios: 1) capture of the entire flow from the small watershed, and 2) sheetflow capture from the Barren Wash alluvial fan watershed. This proved to be unnecessary, owing to the ratios of the watershed areas and the U5a diameter to the alluvial fan contour passing through it; that is, the ratio of the Barren Wash alluvial fan watershed area to the smaller watershed is $(14.5 / 0.65)=22.3$. The width of the alluvial fan contour passing through U5a is $2,591 \mathrm{~m}$, and the diameter of U5a projected onto this contour is approximately $116 \mathrm{~m}$. Therefore, the sheetflow capture fraction is $\left(\mathrm{W}_{\mathrm{c}} / \mathrm{W}_{\mathrm{w}}\right)=0.045$. It can be 
easily shown that the effect of the larger area is almost exactly offset by the capture fraction. Therefore, only a single flow capture scenario was examined.

\section{Soil Conditions}

Maps characterizing the hydrologic properties of soils on the NTS were not available, but previous studies (Schmeltzer et al., 1993) characterized the soils in the vicinity of U5a as having an Antecedent Moisture Condition II (AMC-II) curve number of 77, with corresponding AMC-I and AMC-III values of 59 and 87, respectively. During the summer period, it is likely that AMC-I conditions prevail. While frozen soils would result in higher curve numbers, studies at the nearby Area 5 RWMS show that soils in this area freeze only infrequently during the winter months (M. Sully, 1997, Bechtel Nevada, pers. comm.). Therefore, given the small probability of precipitation on frozen ground at this location, this scenario is ignored. As will be discussed below, three "soil condition" scenarios were modeled for runoff predictions. In the first scenario, AMC-I conditions were assumed to exist throughout the year. In the second scenario, AMC-I conditions were assumed to exist in the summer period (May - September, inclusive) and AMC-II conditions in the winter period. In the third scenario, AMC-II conditions were assumed to exist throughout the year.

\section{U5a Stage-Volume Relationship}

The lowest point in the crater (according to the post-test topographic data) is approximately $912 \mathrm{~m}$ above mean sea level. U5a has a surface area of $10,680 \mathrm{~m}^{2}$ and a volume of $104,230 \mathrm{~m}^{3}$. It is pertinent to observe that the average annual depth of precipitation at well $5 \mathrm{~B}$ is $126 \mathrm{~mm}$; therefore, on the average, $1,346 \mathrm{~m}^{3}$ of water fall directly into the crater each year. This observation is important in judging the reasonableness of the simulation results.

\section{Surface Water Simulation Results}

The results of a 32-year simulation period are summarized in Table 5. Scenarios 2 and 3 result in the crater capturing more water than Scenario 1. However, the relationship between the curve number and capture is subtle, since, in this case, the curve number only affects the runoff from the upstream watershed and has no effect on the precipitation falling directly on the crater. The captured water reported in this table was the combination of runoff from the watershed and precipitation that fell directly into the crater. In some cases, all the capture resulted from precipitation directly into the crater, and in all cases, direct precipitation into the crater is a major percentage of the total water captured. For instance, no surface water runoff was generated in Scenario 1, and all the reported capture in Table 5 for this scenario was the result of precipitation directly into the crater. In cases where no runoff is generated from the watershed, it is assumed that ponding does not occur in the crater.

On the average, Scenarios 2 and 3 result in the crater receiving approximately $62 \mathrm{~m}^{3}$ of water more per year than Scenario 1. Given the standard deviations associated with these average 
Table 5. Simulation of Water Capture Over a 32-Year Period at Crater U5a Using Three Different AMC CN Scenarios. Scenario 1 (CN 59 For All Months), Scenario 2 (CN 59 For Months May - September, CN 77 For Months October - April), and Scenario 3 (CN 77 For All Months).

\begin{tabular}{|c|c|c|c|c|c|c|}
\hline \multirow[b]{2}{*}{$\begin{array}{l}\text { Simulation } \\
\text { Year }\end{array}$} & \multicolumn{2}{|c|}{ AMC Scenario 1} & \multicolumn{2}{|c|}{ AMC Scenario 2} & \multicolumn{2}{|c|}{ AMC Scenario 3} \\
\hline & $\begin{array}{l}\text { Annual } \\
\text { Capture } \\
\mathrm{m}^{3}\end{array}$ & $\begin{array}{c}\text { Maximum Event } \\
\mathrm{m}^{3} \\
\text { (month) }\end{array}$ & $\begin{array}{c}\text { Annual } \\
\text { Capture } \\
\mathrm{m}^{3}\end{array}$ & $\begin{array}{c}\text { Maximum Event } \\
\mathrm{m}^{3} \\
(\mathrm{month})\end{array}$ & $\begin{array}{l}\text { Annual } \\
\text { Capture } \\
\mathrm{m}^{3}\end{array}$ & $\begin{array}{l}\text { Maximum } \\
\text { Event } \mathrm{m}^{3} \\
\text { (month) }\end{array}$ \\
\hline 1 & 1912 & 395 (Aug) & 2541 & $876(\mathrm{Feb})$ & 2553 & 876 (Feb) \\
\hline 2 & 1591 & 296 (Oct) & 1591 & 321 (Jan) & 1591 & 321 (Jan) \\
\hline 3 & 1381 & 247 (Nov) & 1381 & 247 (Nov) & 1381 & 247 (Nov) \\
\hline 4 & 1147 & 173 (Jul/Aug) & 1147 & 173 (Jul/Aug) & 1147 & 173 (Jul/Aug) \\
\hline 5 & 1406 & $247($ Jan $)$ & 1406 & $247(\mathrm{Dec})$ & 1419 & $247($ Jan $)$ \\
\hline 6 & 678 & 160 (Nov) & 678 & 160 (Nov) & 678 & 160 (Nov) \\
\hline 7 & 1159 & $210(\mathrm{Sep})$ & 1159 & 222 (Mar) & 1159 & 222 (Mar) \\
\hline 8 & 1468 & 333 (Feb/Sep) & 1567 & 333 (Feb/Mar/Sep) & 1690 & 456 (Sep) \\
\hline 9 & 1147 & 185 (May/Nov) & 1147 & 123 (Nov) & 1147 & 185 (May/Nov) \\
\hline 10 & 1628 & 370 (Mar) & 1628 & 370 (Mar) & 1628 & 370 (Mar) \\
\hline 11 & 1949 & 333 (Aug) & 2035 & 333 (Aug) & 2035 & 333 (Aug) \\
\hline 12 & 950 & 259 (Aug) & 950 & 259 (Aug) & 950 & 259 (Aug) \\
\hline 13 & 1604 & 271 (Jan) & 1604 & $395(\mathrm{Jul})$ & 1604 & $395(\mathrm{Jul})$ \\
\hline 14 & 1320 & 395 (Jan) & 1344 & 419 (Jan) & 1344 & 419 (Jan) \\
\hline 15 & 1678 & 259 (Nov) & 1678 & 259 (Nov) & 1678 & 259 (Nov) \\
\hline 16 & 1542 & $456(\mathrm{Jan})$ & 2442 & 1369 (Jan) & 2442 & 1369 (Jan) \\
\hline 17 & 863 & 284 (Mar) & 863 & 284 (Mar) & 863 & 284 (Mar) \\
\hline 18 & 1628 & $530(\operatorname{Jan})$ & 1641 & $530($ Jan $)$ & 1641 & 530 (Jan) \\
\hline 19 & 1110 & 358 (Feb) & 1110 & $358(\mathrm{Feb})$ & 1122 & $358(\mathrm{Feb})$ \\
\hline 20 & 1283 & 247 (Jan) & 1480 & $358(\operatorname{Jan})$ & 1480 & 358 (Jan) \\
\hline 21 & 691 & 247 (Aug) & 691 & 247 (Aug) & 691 & 247 (Aug) \\
\hline 22 & 1912 & 395 (Mar) & 1912 & 395 (Mar) & 1937 & 395 (Mar) \\
\hline 23 & 1419 & 333 (Jan) & 1419 & 333 (Jan) & 1419 & 333 (Jan) \\
\hline 24 & 1641 & 493 (Aug) & 1653 & 493 (Aug) & 1653 & 493 (Aug) \\
\hline 25 & 1974 & 345 (Jan) & 1974 & 345 (Jan) & 1974 & 345 (Jan) \\
\hline 26 & 999 & 395 (Feb) & 1135 & $530(\mathrm{Feb})$ & 1135 & $530(\mathrm{Feb})$ \\
\hline 27 & 888 & $234(\mathrm{Feb})$ & 888 & $234(\mathrm{Feb})$ & 888 & 234 (Feb) \\
\hline 28 & 1690 & 321 (Jan/Nov) & 1727 & 333(Jan/Nov) & 1776 & 333 (Jan/Nov) \\
\hline 29 & 1678 & $444(\mathrm{Feb})$ & 1789 & $555(\mathrm{Feb})$ & 1789 & $555(\mathrm{Feb})$ \\
\hline 30 & 1665 & 493 (Aug) & 1665 & 493 (Aug) & 1665 & 493 (Aug) \\
\hline 31 & 1332 & 370 (Mar) & 1332 & 370 (Mar) & 1332 & 370 (Mar) \\
\hline 32 & 1184 & 210 (Aug) & 1184 & 210 (Aug) & 1184 & 210 (Aug) \\
\hline Average $\mathrm{m}^{3} \mathrm{yr}^{-1}$ & 1394 & & 1456 & & 1468 & \\
\hline $\begin{array}{l}\text { Standard } \\
\text { Deviation } \mathrm{m}^{3} \mathrm{yr}^{-1}\end{array}$ & 358 & & 444 & & 444 & \\
\hline
\end{tabular}


values, the statistical difference among these average values is probably not significant. A majority of the precipitation events resulting in capture occurs during the winter months. For example, in the case of Scenario 2 (Column 5) in the 32 simulated years, 24 took place in the winter period (October - April) and 9 in the summer period (June - September). Note, in year eight there was an equal number of maximum events in the summer and winter periods. This is significant in that during the winter period, evapotranspiration is at a minimum; therefore, the potential for infiltration is higher than during the summer period. Scenario 2 is likely the most representative of actual conditions.

\section{Field Monitoring Results}

During the time period of March 1996 through July 1997, wind speed, air temperature, precipitation, pond stage, and soil moisture were monitored. Figure 4 depicts the minimum, maximum, and average air temperature (top figure), and the maximum, minimum, and average wind speeds recorded at the meteorological station located in the U5a crater bottom. A maximum temperature of $44.9^{\circ} \mathrm{C}$, minimum of $-10.5^{\circ} \mathrm{C}$, and an average of $12.3^{\circ} \mathrm{C}$ were recorded during the study. Maximum, minimum, and average wind speeds recorded were $5.0 \mathrm{~m} / \mathrm{s}, 0 \mathrm{~m} / \mathrm{s}$, and $0.71 \mathrm{~m} / \mathrm{s}$, respectively. A total of $101 \mathrm{~mm}$ of precipitation was recorded in the U5a crater. The bottom half of Figure 5 illustrates the daily precipitation totals and the maximum precipitation recorded in a 15-minute interval. The top half of Figure 5 shows the two very small ponding events that were recorded during the study. Note that each ponding event is less than $30 \mathrm{~mm}$ in depth and probably represents only very local runoff, perhaps only from the outer edges of the playa. Figure 6 depicts the two ponding events in more detail, revealing that the first ponding event (top of Figure 6) lasted less than one day, while the second event remained for about two days. This is probably a result of a wetter surface soil condition that likely existed based on the precipitation data shown in Figure 5.

Neutron moisture monitoring performed periodically throughout the study indicated no detectable changes in volumetric moisture conditions either in or out of the crater environment (Figure 7). In borehole U5a-n1, excluding the upper few meters, which were artificially wetted during borehole construction, volumetric moisture values ranged from 5 to 20 percent, based on neutron logging. The upper couple of meters of soil remain wetted because this portion of the borehole was completed with bentonite pellets to ensure a seal around the neutron access tube. In borehole U5a-n2, volumetric moisture conditions ranged from between 5 and 10 percent. It should be noted that deeper moisture penetration was certainly not expected given the small quantity of precipitation received and the two small ponding events recorded. 


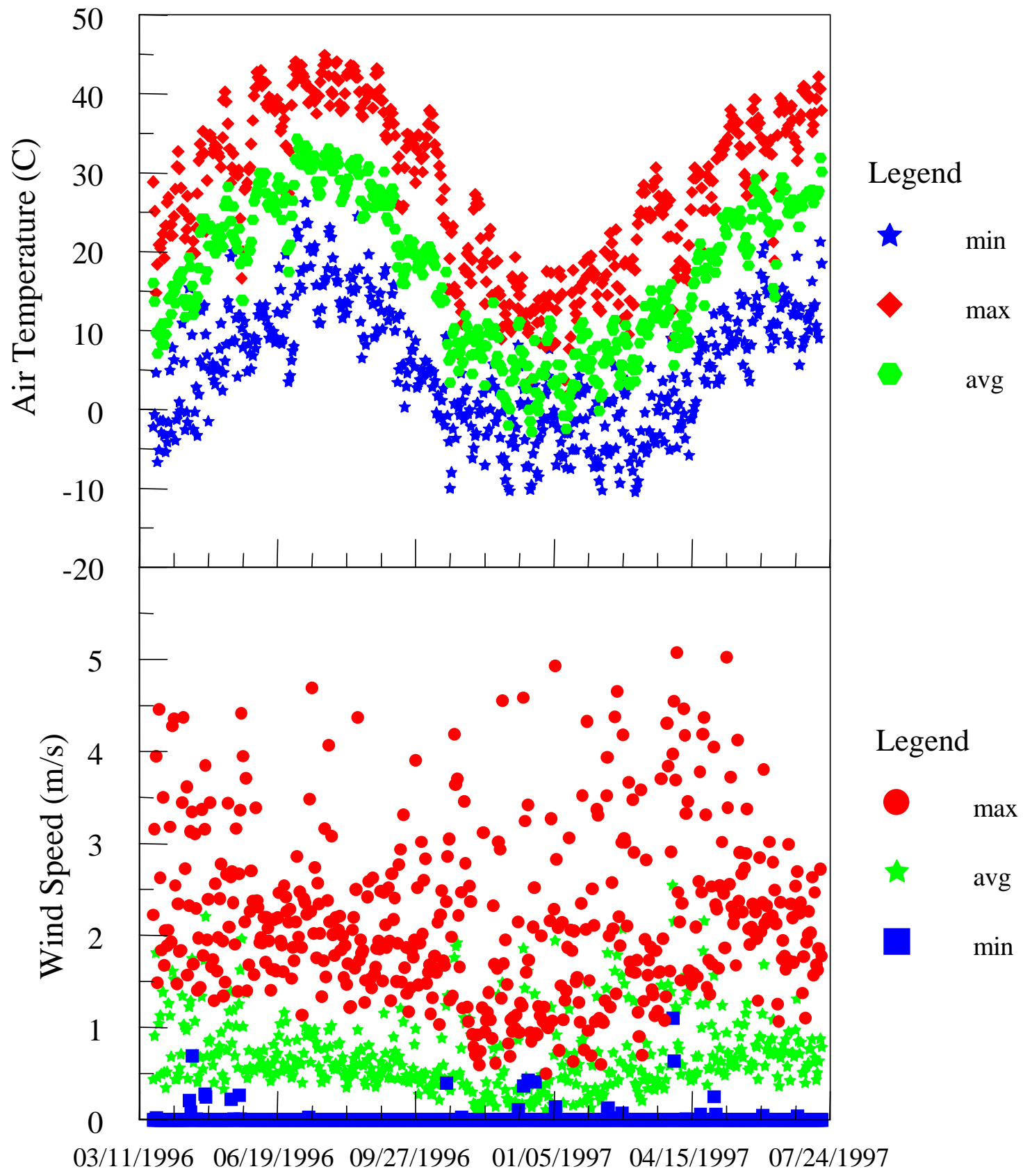

Date

Figure 4. Plots of air temperature and wind speeds recorded at crater U5a. 


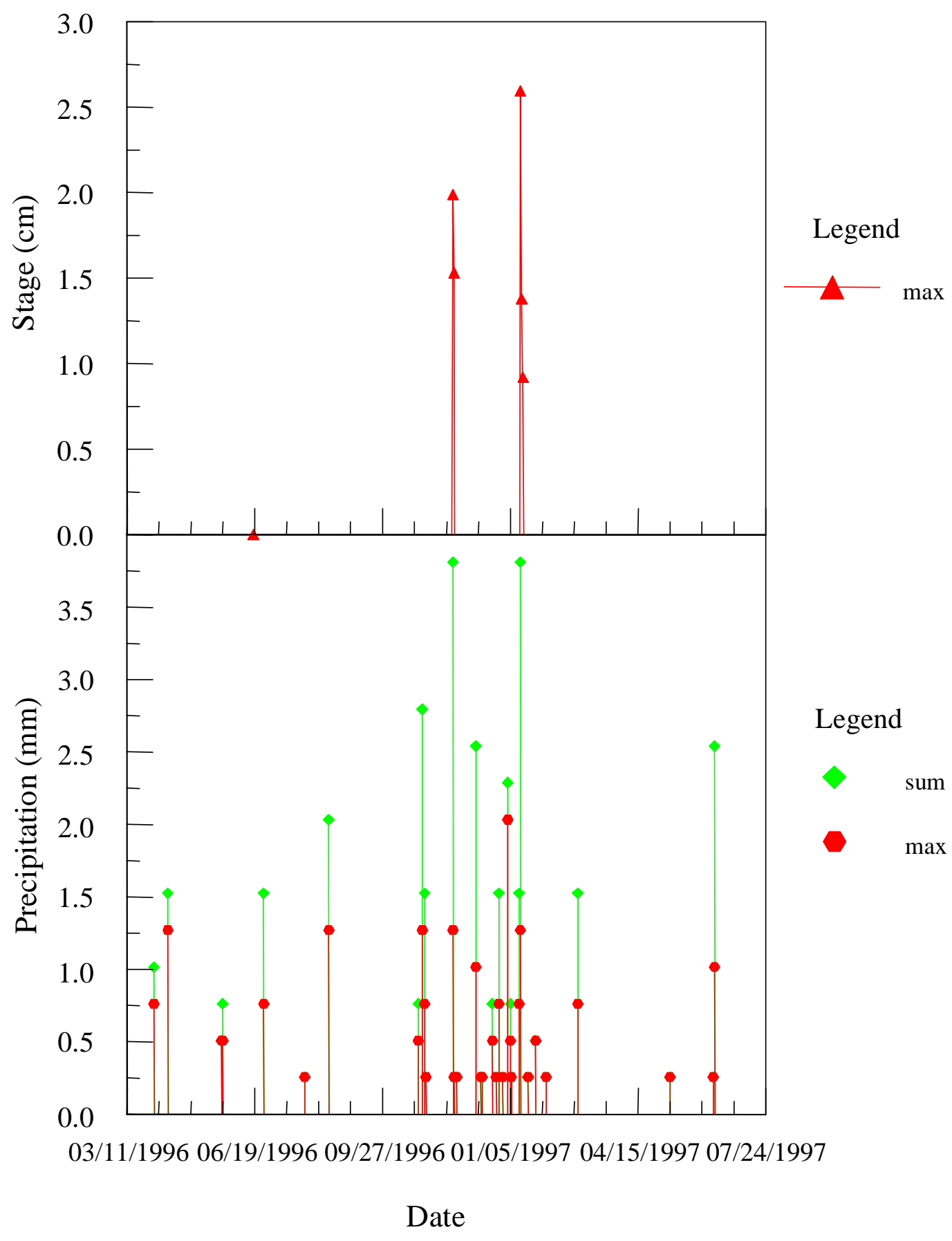

Figure 5. Maximum precipitation recorded per 15-minute interval and daily totals (bottom graph). Two small ponding events (top graph). 

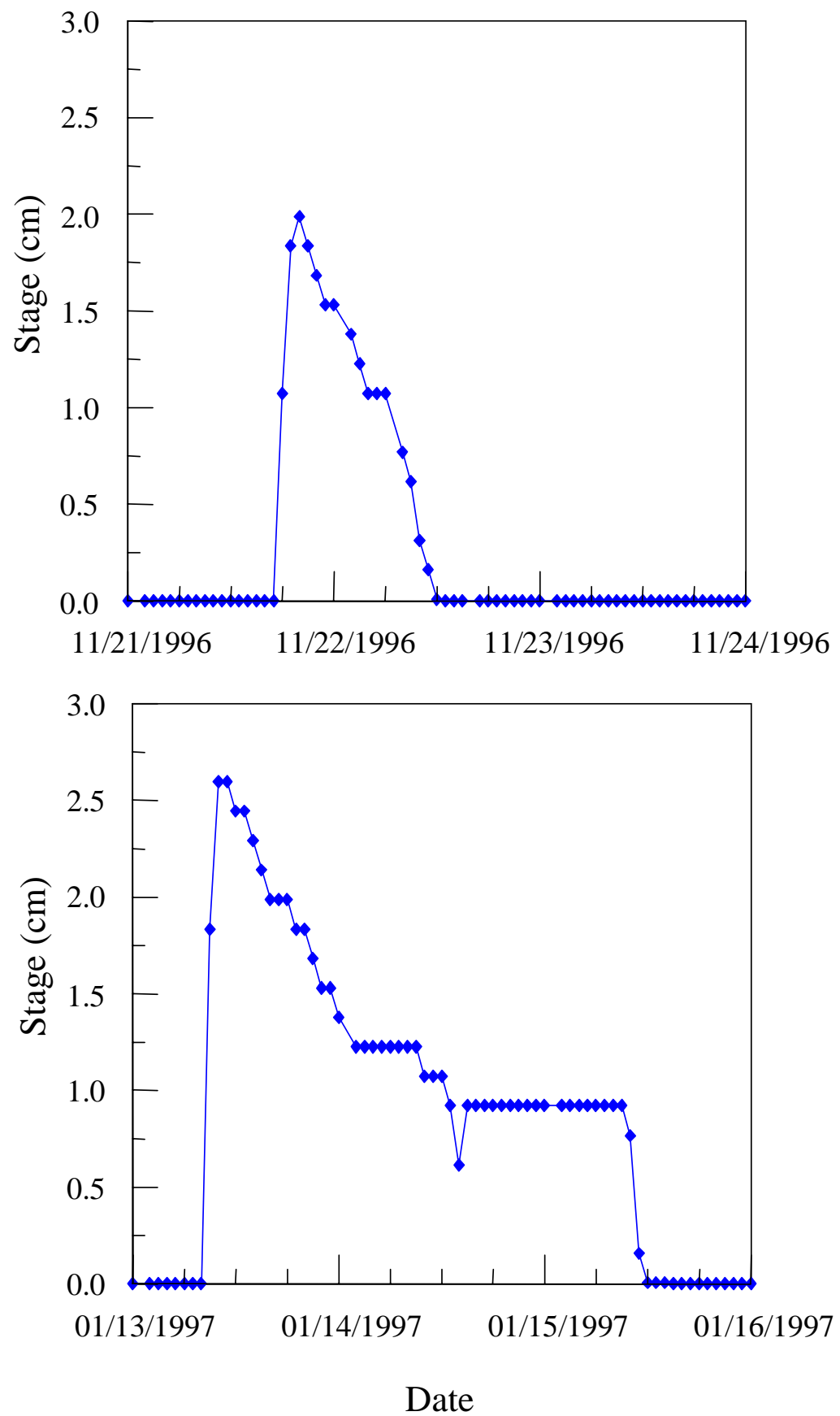

Figure 6. Detailed views of the two small ponding events recorded at crater U5a. 


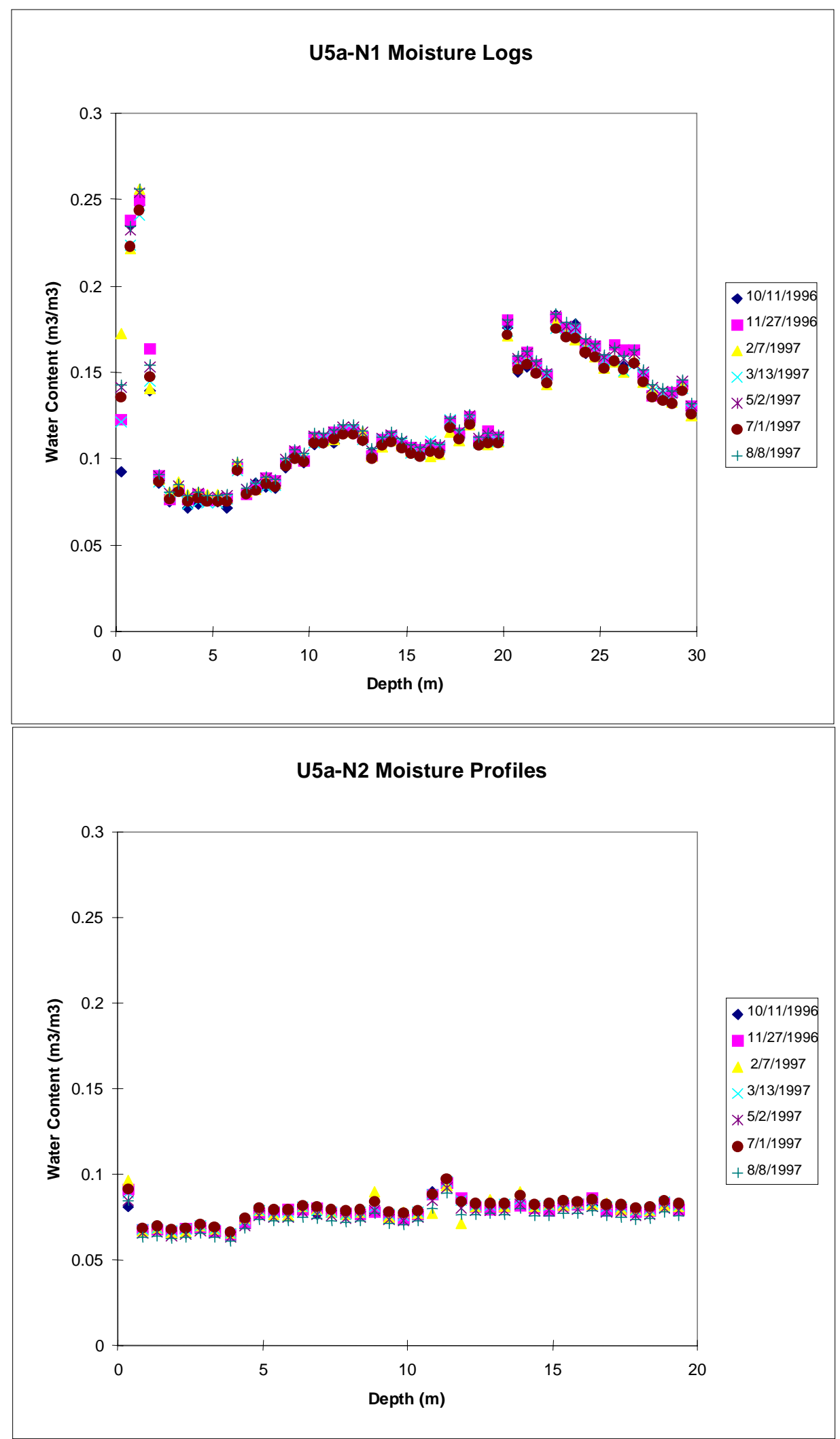

Figure 7. Soil moisture profiles measured with the neutron moisture meter for wells U5a-n1 and n2. U5a-n2 is located outside the crater environment. 


\section{Vadose Zone Modeling Results}

During 1996, two boreholes were augered to determine the hydraulic properties of the soils beneath the crater and outside the crater environment (Hokett and Gillespie, 1996). These results indicated that the upper $3 \mathrm{~m}$ of material in the crater bottom had hydraulic conductivities in the range found for silt loams, with a saturated hydraulic conductivity of $10^{-5} \mathrm{~cm} \mathrm{sec}^{-1}$. From 3 to $10 \mathrm{~m}$ below the playa center, results indicated that the material was most similar to a loam soil, with a saturated hydraulic conductivity of $10^{-4} \mathrm{~cm} \mathrm{sec}^{-1}$. Below $10 \mathrm{~m}$, the soil is best characterized as a loamy sand with a saturated hydraulic conductivity of $10^{-3} \mathrm{~cm} \mathrm{sec}^{-1}$. Results from the borehole drilled outside the crater indicated that soil outside the playa area was also best represented by the properties of a loamy sand. Hydraulic parameters were selected based upon measured soil texture from the HYDRUS2D soils catalog, which obtained its parameters from Carsel and Parrish (1988). The values used for the three soil types, plus those used in Area 5 RWMS modeling work by Crowe et al. (1998), are shown in Table 6. The vertical axial symmetry feature of the HYDRUS2D model was used to model ponding events and subsequent infiltration and redistribution in the U5a crater. A model domain with a radius of $20 \mathrm{~m}$ and a height of $200 \mathrm{~m}$ was established using the three materials described above. The playa was approximated to have a radius of $10 \mathrm{~m}$, and thus extended out horizontally from 0 to $10 \mathrm{~m}$, with a vertical thickness of $3 \mathrm{~m}$, and was characterized as a silt loam.

A loam material was used below this playa layer, extending out horizontally $10 \mathrm{~m}$ and beginning at a vertical depth of $3 \mathrm{~m}$ and extending to a depth of $10 \mathrm{~m}$. The entire remainder of the domain was comprised of a sandy loam material (Figure 8).

With the exception of the above three layers, the remainder of the modeling approach assumes a homogeneous material, i.e., no layering. While layering is evident in soil trenches from the Area 5 RWMS and certainly variations in texture were found in the samples collected during drilling, it was judged that the lateral continuity of any layers beneath the crater bottom would have been disrupted during the cratering process. In a horizontal continuous layering situation, layering serves to reduce the depth of wetting front advancement, particularly during later redistribution times. If soil layers are preserved in a crater upon collapse, they would slope inward and likely enhance recharge due to convergent flow. Treatment of the vadose zone as a non-layered system will then provide representative recharge rates.

Given the low saturated hydraulic conductivity of the crater playa materials, moisture penetration through this material is unlikely to infiltrate deeply enough to escape extraction by evaporation, as was indicated in the previous year's preliminary modeling results. However, ponded water which comes in contact with the sandy material adjacent to the crater playa bottom would allow rapid infiltration of water to depths thought to be beyond the depth of extraction by evapotranspiration (Hokett and Gillespie, 1996). Given the very flat and well-defined topography of the playa bottom, even the smallest of ponding events simulated would spread laterally far enough to be in contact with the sandy material. This is based on a limited topographic survey 
Table 6. Van Genuchten Parameters for U5a Report and Crowe et al. (1998).

\begin{tabular}{lcccc}
\hline Parameter Description & $\begin{array}{c}\text { Silt Loam } \\
\text { (playa } \\
\text { material) }\end{array}$ & $\begin{array}{c}\text { Loam } \\
\text { (material } \\
\text { beneath playa) }\end{array}$ & $\begin{array}{c}\text { Loamy Sand } \\
\text { (remainder } \\
\text { of domain) }\end{array}$ & $\begin{array}{c}\text { Crowe } \text { et } \\
\text { al., } 1998\end{array}$ \\
\hline Saturated Hydraulic conductivity $\left(\mathrm{m} \mathrm{day}^{-1}\right)$ & 0.06 & 0.25 & 3.5 & 0.639 \\
Van Genuchten " $\mathrm{n}$ " parameter & 1.37 & 1.56 & 2.28 & 1.9 \\
Residual Water Content $\left(\mathrm{m}^{3} \mathrm{~m}^{-3}\right)$ & 0.034 & 0.078 & 0.057 & 0.075 \\
Saturated Water Content $\left(\mathrm{m}^{3} \mathrm{~m}^{-3}\right)$ & 0.46 & 0.43 & 0.41 & 0.361 \\
Van Genuchten "alpha" parameter $\mathrm{m}^{-1}$ & 1.6 & 3.6 & 12.4 & 1.831 \\
\hline
\end{tabular}

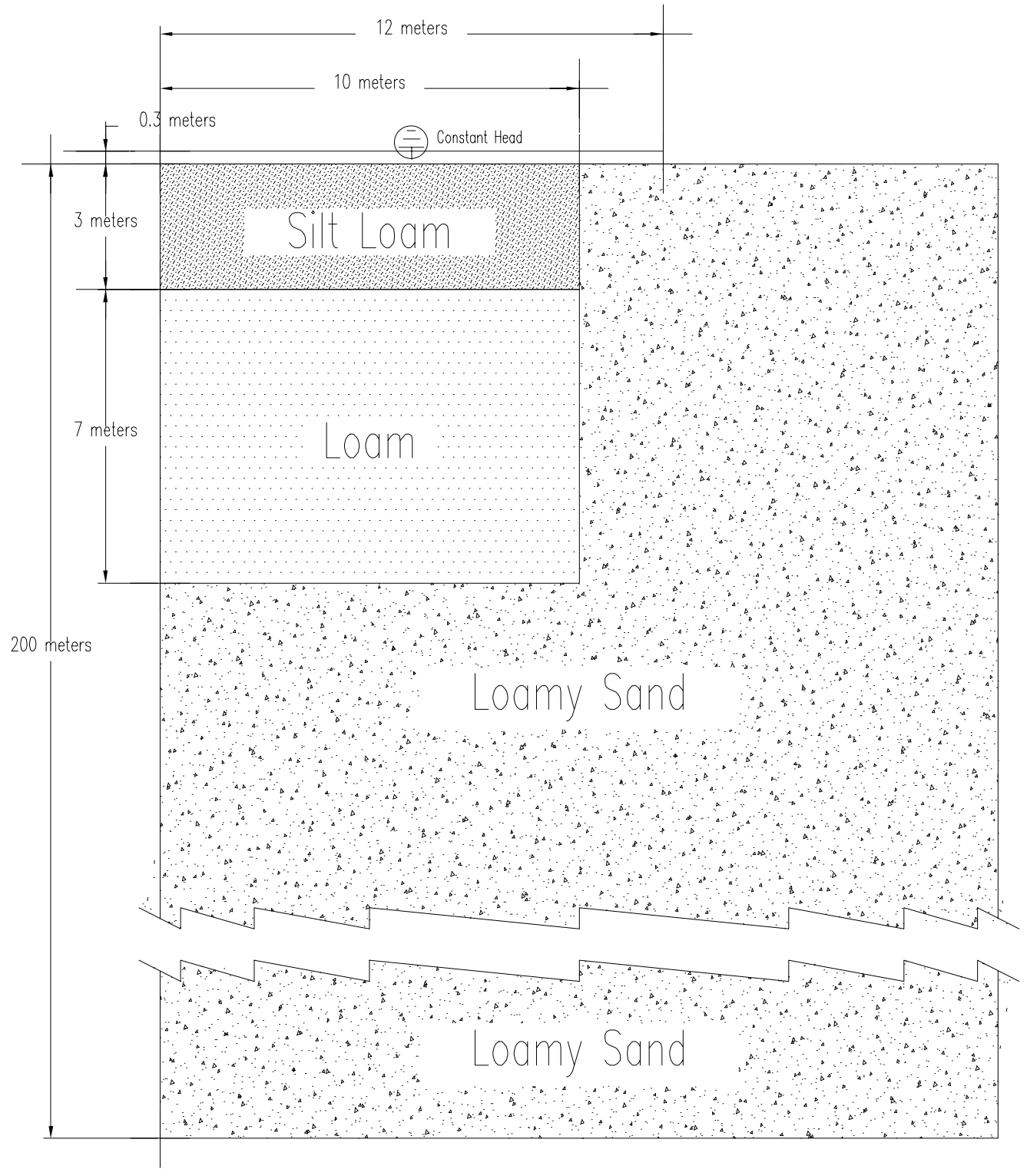

Figure 8. U5a material distribution used for vadose zone modeling. 
conducted during 1996. Stage-volume relationship developed for the crater indicated that an average ponding event would have a depth of approximately $0.3 \mathrm{~m}$. Thus, each ponding event was modeled with a constant head boundary of $0.3 \mathrm{~m}$, which extended $2 \mathrm{~m}$ beyond the crater playa surface and onto the sandy loam (Figure 8). The actual head and lateral spread of the ponds would change during each ponding event and would vary from ponding event to ponding event; however, holding these boundary conditions constant greatly simplified the modeling effort. Allowing the ponds to extend out further laterally would likely have resulted in shallower infiltration and would have produced less potential recharge. Thus, by restricting the pond's lateral extent out to only $2 \mathrm{~m}$ beyond the playa edges, recharge estimates would be a conservative scenario in terms of contaminate transport potential.

Results from the surface water modeling using Scenario 2 conditions (Table 5) (wet soils in the winter months and dry soils in the summer months) were used to estimate the timing and magnitude of ponding events during the life of the crater (Table 7). The ponding events shown in Table 7, represent precipitation events presented in Table 5, which produced surface water runoff. In many of the events depicted in Table 5, no runoff was produced and the event was composed solely of direct precipitation into the crater. This precipitation was applied in the vadose zone model as an average monthly precipitation rate. Scenario 2 conditions were used because they were thought to be the most realistic for Area 5. Additionally, little difference was found between Scenario 2 and 3 conditions, mainly because most of the larger precipitation events were winter frontal storms and both scenarios use wet soil conditions in the winter. Further, using Scenario 1 conditions resulted in no ponding events, which was obviously not correct based on the field evidence.

Table 7. The Volume of Ponding Events and Their Timing as Predicted by the Surface Water Modeling. Pond volume is a combination of direct precipitation in the crater and runoff from the drainage area.

\begin{tabular}{ccc}
\hline Simulation Year & Month & Pond Volume $\left(\mathrm{m}^{3}\right)$ \\
\hline 1 & 10 & 382 \\
8 & 3 & 333 \\
11 & 3 & 271 \\
14 & 1 & 419 \\
16 & 1 & 1369 \\
18 & 1 & 530 \\
20 & 1 & 357 \\
20 & 4 & 284 \\
24 & 1 & 209 \\
26 & 2 & 530 \\
28 & 1 & 333 \\
28 & 11 & 333 \\
29 & 2 & 555 \\
\hline
\end{tabular}


During months when runoff was generated from the drainage area, this volume of water was combined with the volume of water which fell directly into the crater to determine the magnitude of the ponding event. In total, 13 ponding events predicted by the surface water model were simulated using the HYDRUS2D vadose zone model described earlier. The average pond volume was $484 \mathrm{~m}^{3}$, the maximum was $1,370 \mathrm{~m}^{3}$ and the minimum event was $209 \mathrm{~m}^{3}$. The total volume of ponded water for the entire simulation period was approximately $5,900 \mathrm{~m}^{3}$. Each ponding event was simulated until the pond volume completely infiltrated into the soil, as indicated by the change in mass balance calculated by the vadose zone model. Evaporation during ponding events was not included primarily because the infiltration through the sandy material was rapid enough to allow infiltration of the entire pond volume in less than one day in all cases studied. Thus, the effects of evaporation during the event were negligible. Following each ponding event, infiltration and moisture redistribution were modeled with a potential evaporation rate of $0.8 \mathrm{~cm}_{\text {day }}{ }^{-1}$ until the beginning of the next ponding event. Plant transpiration was not incorporated in the modeling because of the lack of information on the plant transpiration and rooting depths. Additionally, this adds to the conservatism of the modeling.

In the time intervals between ponding events, moisture redistribution, precipitation, and surface evaporation were modeled. The precipitation values used were those from the well 5B precipitation station. The total monthly precipitation recorded was applied in the model on an evenly distributed daily basis for practical considerations of the modeling effort. While this approach is not strictly accurate, it was thought sufficient for these purposes primarily because precipitation alone in the Frenchman Flat area has been shown in several studies not to produce moisture penetration beyond the very near surface (less than $1 \mathrm{~m}$ ) (Hokett, 1995). However, precipitation was not completely neglected because this would have had the effect of enhancing the evaporation rate. A potential evaporation rate of $0.8 \mathrm{~cm} /$ day was used in all the modeling simulations. This rate is thought to represent the yearly average potential evaporation rate based on pan evaporation rate measurements from the area (Magnuson et al., 1992). However, the actual evaporation rate cannot exceed the hydraulic conductivity of the surface soils; thus, the actual evaporation rate is always lower than the potential evaporation rate. The duration of the redistribution period was controlled by the temporal spacing of the ponding events, which averaged 2.2 years, had a minimum spacing of 0.3 years and a maximum of 6.4 years.

Figures 9, 10, 11, and 12 depict the moisture profiles at the end of each ponding event and the end of each subsequent moisture redistribution event, simulated by the vadose zone model. The end of each ponding event was determined when the change in mass balance equaled the pond volume. The end of each redistribution event was determined by the beginning of each ponding event. In each case, a model domain size of $200 \mathrm{~m}$ vertically by $20 \mathrm{~m}$ horizontally was used, though the above figures only show the upper zone where the significant changes were occurring. In each of the seven moisture profiles shown in Figure 9, the upper left-hand corner of the moisture profile represents the center of the playa bottom. The top middle of each moisture profile represents the contact between the playa material and the surrounding loamy sand 


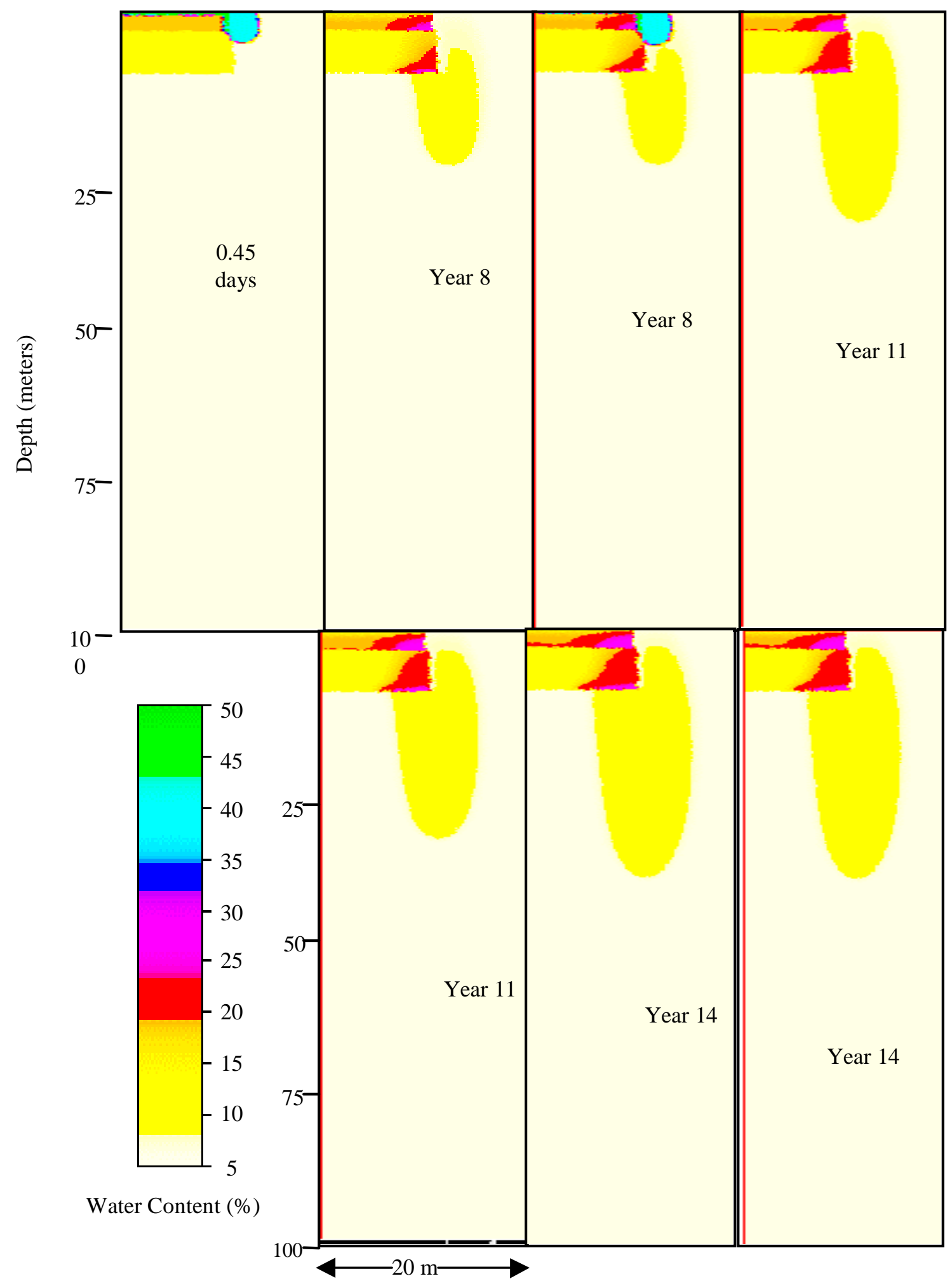

Figure 9. Moisture profiles predicted from surface and vadose zone modeling during the first 14 years of the crater's existence. 


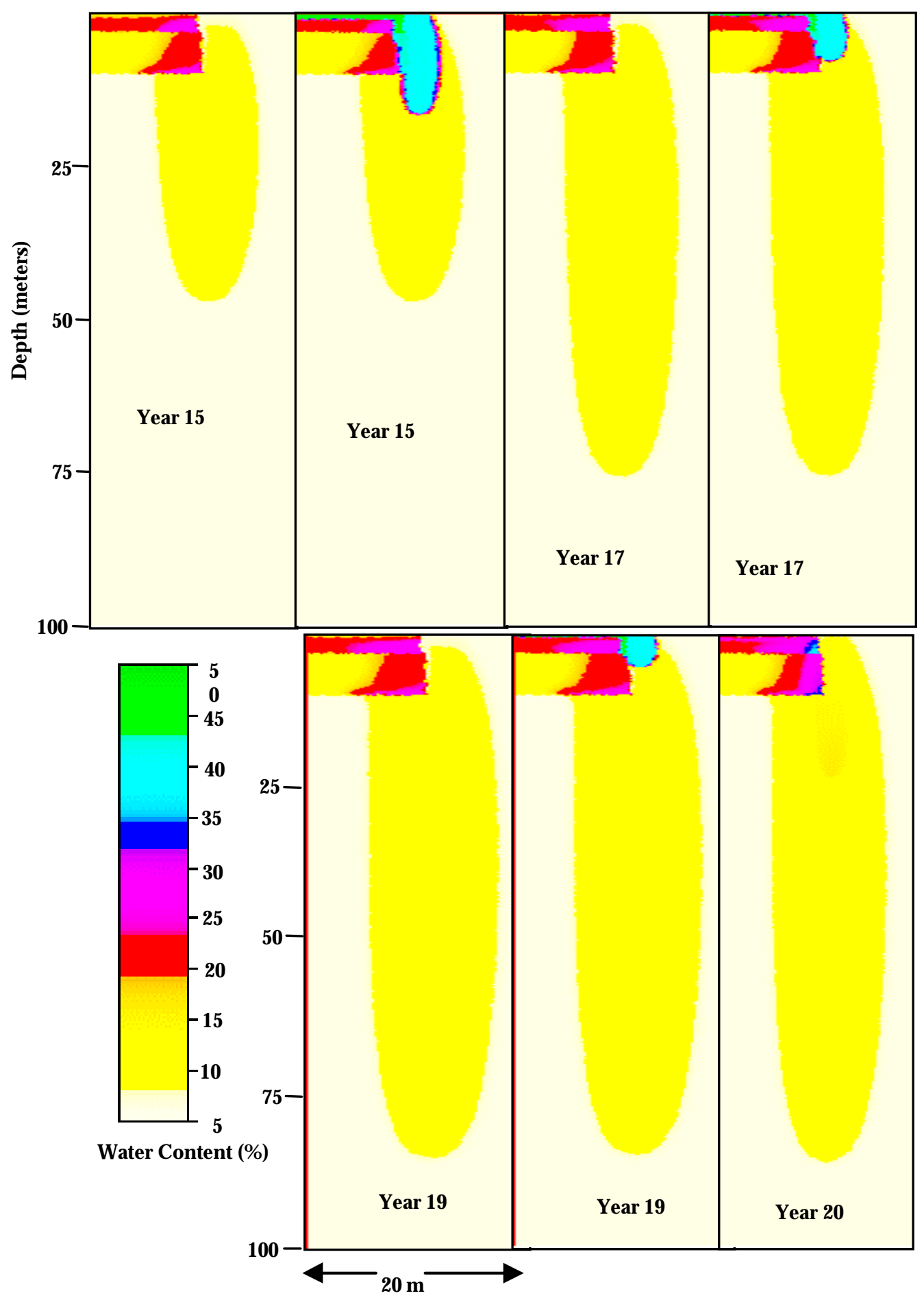

Figure 10. Moisture profiles predicted from surface and vadose zone modeling for years 15 through 20. 


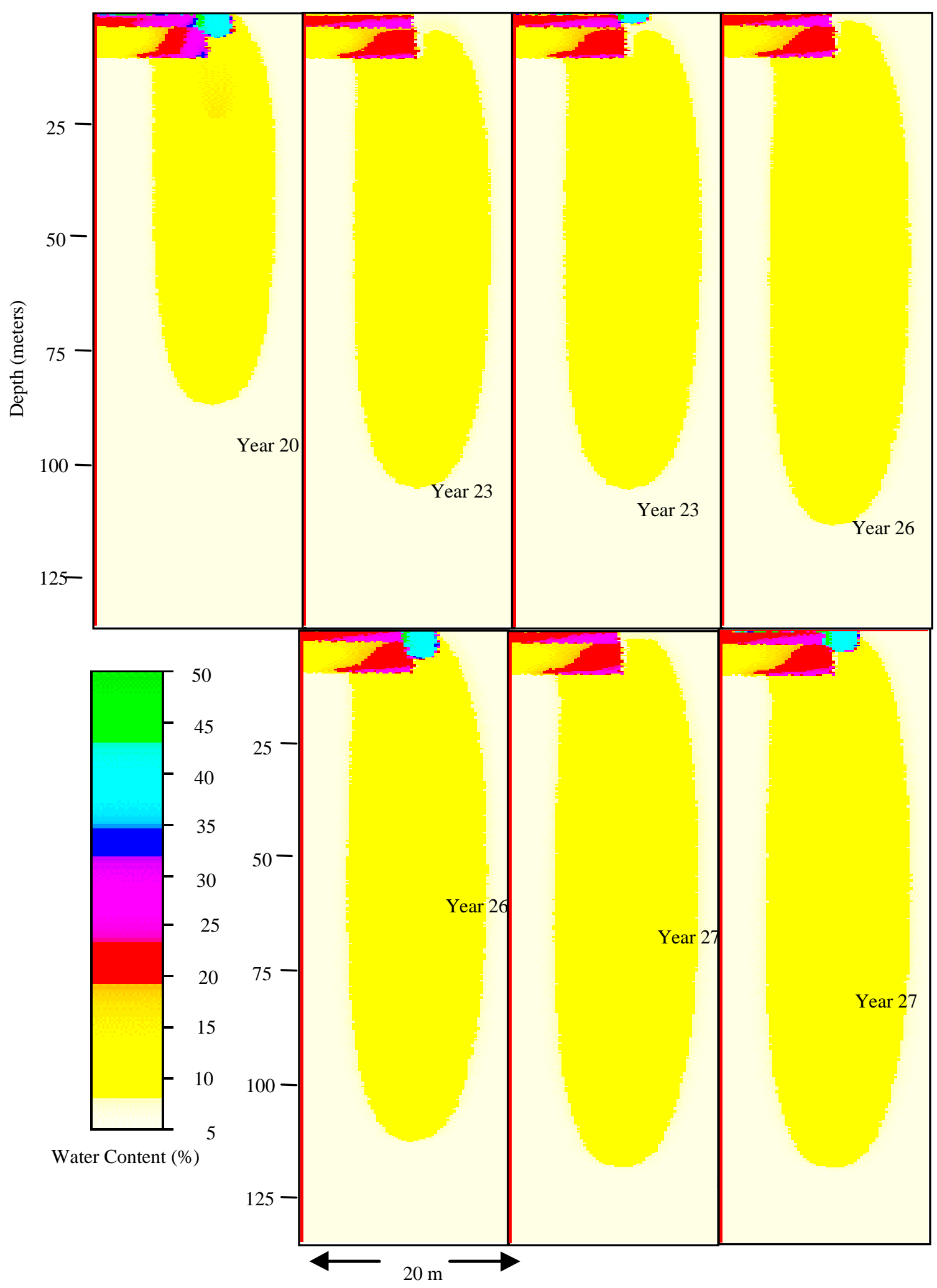

Figure 11. Moisture profiles predicted from surface and vadose zone modeling for years 20 through 27 . 


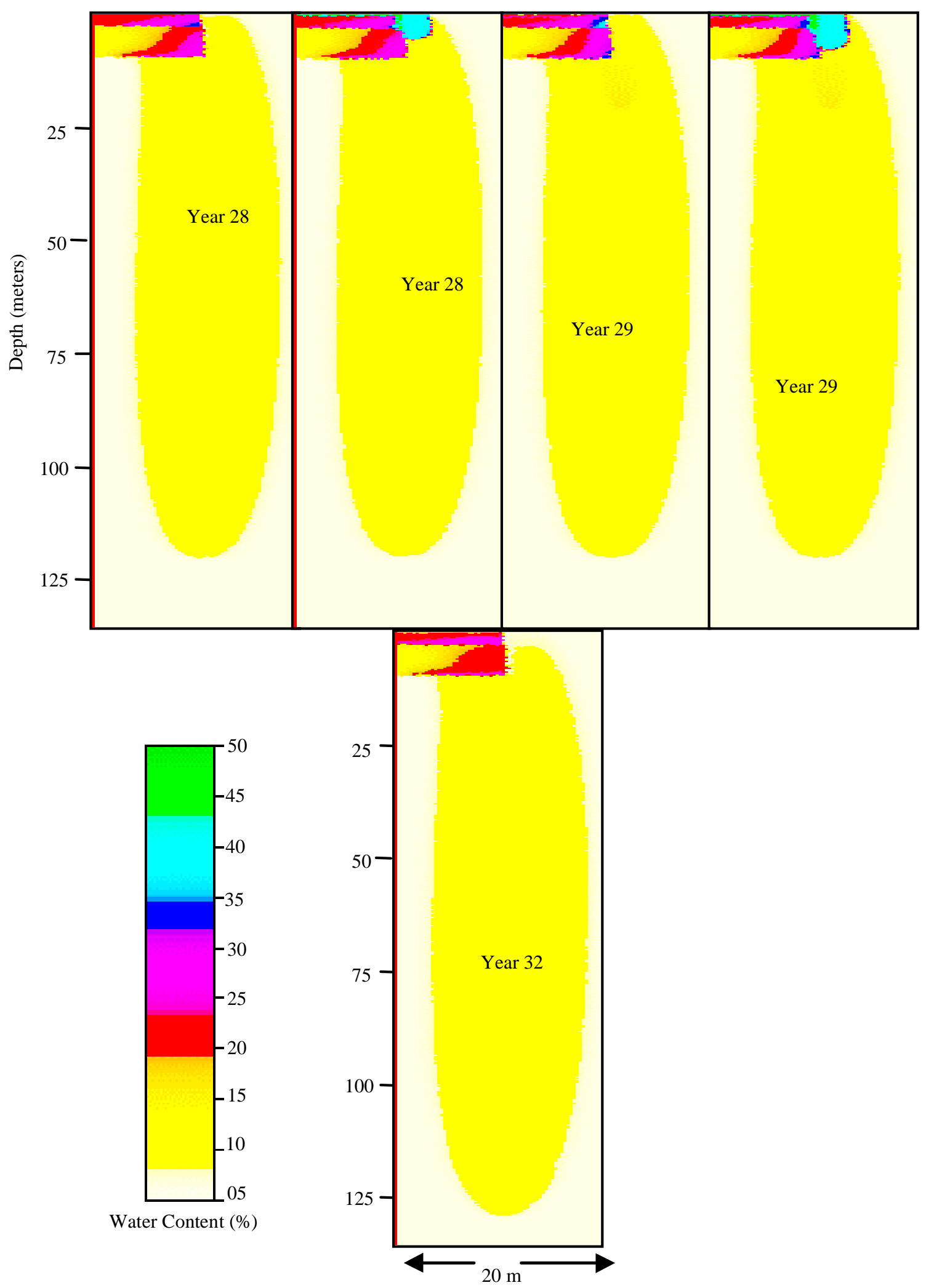

Figure 12. Moisture profiles predicted from surface and vadose zone modeling for years 28 through 32 . 
materials. Thus, the figures clearly show that limited moisture penetration occurred through the playa bottom, but that substantial infiltration occurred through the loamy sand that borders the playa bottom. These results occur because the flood-deposited soils beneath the playa have saturated hydraulic conductivities two orders of magnitude lower than the material surrounding the playa.

As previously mentioned, approximately $5,900 \mathrm{~m}^{3}$ of water were deposited into the crater bottom by the 13 surface water flow events predicted by the surface water model. Modeling indicated that at the end of the 32-year simulation, approximately $5,200 \mathrm{~m}^{3}$ of this water remained in the soils beneath the crater; thus, 12 percent of the water was lost to evaporation. Of the volume remaining in the soil, 96 percent was stored in the loamy sand surrounding the crater, with the remainder in the other two soil zones. The actual potential recharge rate can be calculated by dividing the total storage gain by the surface area of the recharge region. However, the calculation is very sensitive to the surface area used. For instance, if the total surface area upon which ponding was simulated is used, a recharge rate of $36 \mathrm{~cm}_{\text {year }}{ }^{-1}$ is calculated. If only the surface area of the zone extending out $2 \mathrm{~m}$ beyond the playa edge is considered as the recharge zone, then a recharge rate of $118 \mathrm{~cm}_{\text {year }}{ }^{-1}$ is obtained. The latter, would assume, as this analysis mandated, that most of the ponded water rapidly infiltrates at the playa margins without extensive lateral spread and that the volume of water penetrating the playa is minor.

At the end of the 32-year simulation, the wetting front had reached a depth of $129 \mathrm{~m}$, based upon both an abrupt change in water content and water potential (Figure 13). It can also be seen from Figure 13 that the advancement of the deep wetting front is slowing with time as a result of the lateral spreading of the wetted zone. Modeling results show that the bulk of the wetting front advancement occurs for a short period of time following each ponding event and then slows dramatically until the next ponding event. Thus, if runoff waters were prevented from entering the crater by use of flood control structures, wetting front advancement would slow moisture dramatically and a large percentage of this moisture would remain trapped in the vadose zone. However, the increase in moisture storage to the system continues to increase linearly with time. Modeling efforts could be greatly improved if monitoring were to continue until a representative ponding event could be observed and tracked to allow testing of conceptual models of infiltration as well as to calibrate and validate the surface water model.

These results seem to compare reasonably well with Bechtel Nevada studies in both Area 5 and 3 RWMSs. At Area 5, the most applicable work done for comparison with U5a is the Pit 5 subsidence and flooding studies (Crowe et al., 1998). At Pit 5, three 2-m-deep ponding events were simulated in a fully subsided pit, separated by one year of moisture redistribution. Each pond was allowed to infiltrate into Pit 5 for 24 hours and then the ponding condition was ended. At the end of the three ponding events, moisture redistribution was tracked until the wetting front reached the water table. Good agreement is seen in the fact that rapid infiltration and wetting front advancement occurred for a short time following ponding conditions. At Pit 5, the wetting 

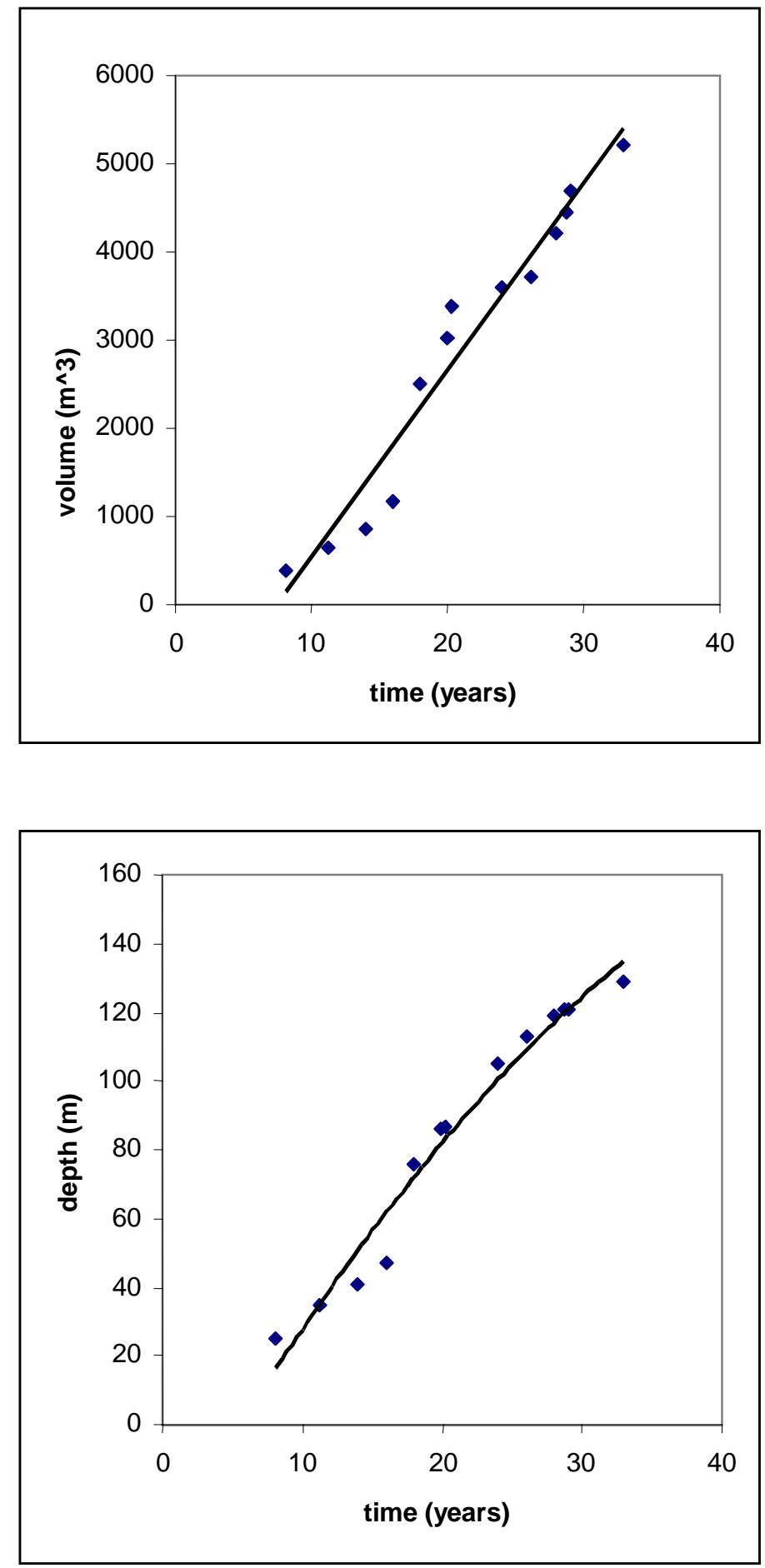

Figure 13. Change in moisture storage (upper plot) and wetting front advancement resulting from simulated ponding events in crater U5a. 
front reached approximately $75 \mathrm{~m}$ within three years. At this point, no further ponds were simulated and the result was a dramatic slowing of the wetting front, requiring 22 additional years for the wetting front to reach $150 \mathrm{~m}$. In comparison with U5a modeling, the wetting front did not reach $75 \mathrm{~m}$ depth until year 18 following six ponding events. Thus, wetting front advancement was moving much faster in the Bechtel Nevada Pit 5 simulations, both in terms of absolute time and in comparison to the number of ponding events. Further comparison shows that at U5a, the wetting front reached $129 \mathrm{~m}$ after 32 years, as compared to the Pit 5 modeling, where the wetting front reached about $140 \mathrm{~m}$ within 25 years. However, in the U5a work, 13 ponding events were required to reach this depth. Again, wetting front advancement was moving faster at Pit 5 than at U5a. Additionally, it is difficult to make a direct comparison between the studies because the volume of water that was allowed to infiltrate at Pit 5 is not known, and the number of ponding events simulated is not the same. Comparison of the two studies does demonstrate though that at both sites, deep infiltration will occur under intermittent pond conditions and that wetting front advancements slow dramatically between ponding events.

To determine the effect of soil properties selection used for modeling, a $400-\mathrm{m}^{3}$ ponding event was simulated using the U5a modeling domain and boundary conditions, but with soil properties from the Area 5 RWMS ponding simulations (Crowe et al., 1998) (Table 6). The soil properties used by Crowe et al. (1998) result in shallower wetting front depths (Figure 14) than the current study by 18 vs. $25 \mathrm{~m}$, respectively. Inspection of the soil parameters in Table 6 for the loamy sand used in the U5a simulations and the parameters used by Crowe et al. (1998) indicates that the most significant differences were between the saturated hydraulic conductivities and the alpha parameter. To determine which of these parameters was most responsible for the differences in the results, a third simulation was run using the Area 5 RWMS soil properties, but with the laboratory-determined U5a saturated conductivities. This resulted in slightly deeper penetration of the wetting front, but results still remained closer to the simulation using the Area 5 RWMS properties; thus, the differences in alpha appear to be having more impact than the Ksat differences.

The alpha parameter is generally related to the saturated hydraulic conductivity. For a given parameter, large values of saturated hydraulic conductivity generally correspond to coarsetextured soils and larger values of alpha. The air entry pressure, i.e., the matric head at which pores drain and air enters, is inversely proportional to alpha, implying that coarser-textured soils have a smaller air entry value. To determine if the HYDRUS2D value of alpha was reasonable for the soil texture found beneath the U5a crater bottom, water retention measurements were conducted by the hanging water column method for low tensions (matric heads near saturation). In all soils tested, an air entry value of less than 0.01-m tension was determined, which would correspond to an alpha value of $10 \mathrm{~m}^{-1}$ or greater. An alpha of $12 \mathrm{~m}^{-1}$ was used for the modeling simulations at U5a and is in good agreement with the measured values used in this report. This is considerably different from the characterization data determined for the Area 5 RWMS used by Crowe et al. (1998) in the Pit 5 modeling simulations $\left(12.4 \mathrm{~m}^{-1} \mathrm{vs} .1 .8 \mathrm{~m}^{-1}\right)$. Characterization 


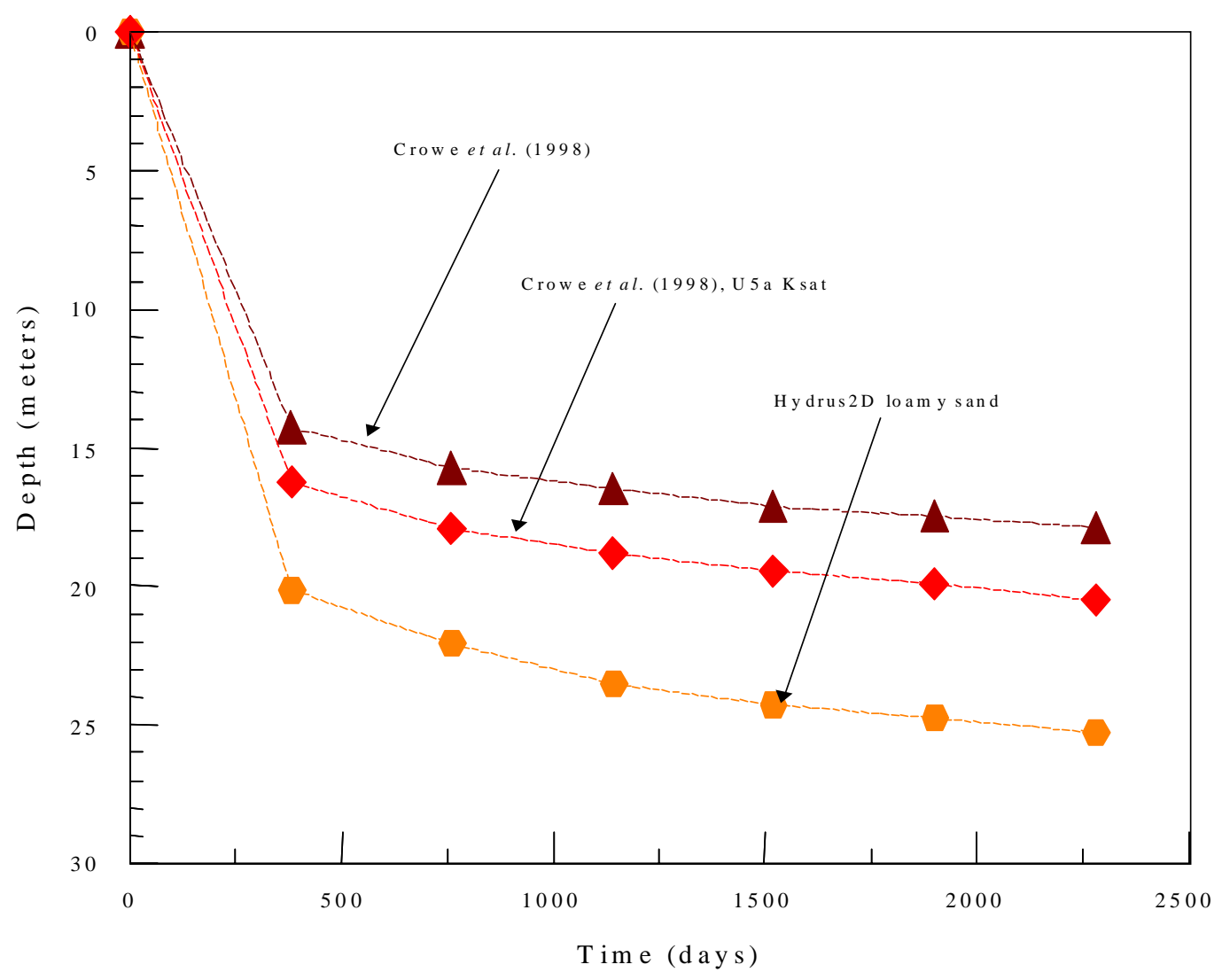

Figure 14. A $400-\mathrm{m}^{3}$ ponding event followed by $\sim 6$ years of moisture redistribution was modeled using three different sets of soil properties.

data at both Areas 5 and 3 RWMSs have shown conclusively that there is no trend with depth in hydraulic parameters (Shott et al., 1997); therefore, there is confidence in using soil parameters that most closely match the data collected in the top $40 \mathrm{~m}$ of soil beneath the crater bottom. As seen in Figure 14, deep infiltration will occur under ponding conditions with a range of soil properties, and wetting front advancement occurs most rapidly following ponding events and then quickly slows down to a nearly immobile status.

In comparison with the Bechtel Nevada work at the Area 3 RWMS, where complete subsidence is followed by a simulated 1,000-year flood event, modeling results indicated that during the first 50 years, the wetting front reached approximately $150 \mathrm{~m}$ and reached the water table at a depth of $492 \mathrm{~m}$ in approximately 950 years (G.J. Shott, 1998, Bechtel Nevada, pers. comm.). This is compared to the modeling at U5a, where the wetting front reached approximately $129 \mathrm{~m}$ after 32 years and 13 ponding events. While these are not directly comparable, both studies again reach the conclusion that deep infiltration can occur under intermittent pond conditions. Again, as in the Pit 5 modeling and the U5a modeling, dramatic wetting front slowing was seen when the surface ponding was discontinued. Though the studies are not directly comparable, similar results were obtained. 
Finally, when comparing U5a modeling results to observed conditions beneath craters in the Area 3 RWMS (Bechtel Nevada, 1998), U5a modeling predicted wetting front advancement to greater depths than was observed in the Area 3 craters. Wetting front advancement maximums were reported to range between 50 and $80 \mathrm{~m}$ in the Area 3 craters, while modeling at U5a predicted wetting front advancement to approximately $129 \mathrm{~m}$. Modeling at U5a predicted greater wetting front advancement by a factor of from 1.6 to 2.6. However, U5a modeling was done from a worst-case-scenario position, by limiting the lateral spread of the ponding events. For example, when considering the recharge area to be the entire crater bottom, plus the lateral spread of $2 \mathrm{~m}$, the calculated recharge rate dropped from $118 \mathrm{~cm}_{\text {year }}{ }^{-1}$ to $36 \mathrm{~cm}_{\text {year }}{ }^{-1}$ as stated previously. Thus, as the potential recharge rate dropped by a factor of approximately three, so would the wetting front advancement predicted by the model if worst-case-scenario conditions had not been employed at the surface. Considering this, plus the fact that the U5a crater has likely received substantially more runoff due to the larger drainage area, the results of the modeling at U5a and the observed field conditions at the Area 3 RWMS compare quite well. Additionally, the lack of erosional features at the Area 3 RWMS further support that these craters have received far less runoff for ponding than U5a.

During the previous year's study, soil samples were collected from boreholes both inside and outside the U5a crater environment. At depth in the crater borehole, soil samples had elevated moisture contents and matric potentials that could only have resulted from deep percolation of moisture following the formation of the crater. It was hypothesized that this moisture resulted from water percolation at the playa margins and then redistribution inward to the position below the playa bottom. In the modeling simulations in this report, rapid percolation around the playa margins was supported; however, moisture migration from the wetting front edges back to the center of the playa where the drill hole was located did not fully occur in these simulations. One explanation is that soil complexities were not accounted for in the model, such as preferential flowpaths or complex layering. These could provide the mechanism for moisture migration from the crater edges back to the center of the playa. This spreading could serve to reduce the recharge rates and delay the arrival of the wetting front at the water table. Alternatively, if layering is tilted toward the center of the crater, recharge rates and wetting front advancement would be accelerated by convergent flow.

Following the conclusion of the modeling work in this report, soil sampling along a transect within the crater bottom revealed that the soil morphology did not match that assumed in the flow domain. Field analysis indicated an upward sequence of progressively finer texture at each location along the transect, suggesting all of this material may have been deposited by a single large flood event. Further inspection of crater photographs revealed a pronounced, waterdeposited sediment line at approximately $5 \mathrm{~m}$ below the rim of the crater. It is not known when this large event occurred. Since the ponding event that deposited this material preceded the current playa bottom material, infiltration could occur directly through the original crater bottom, rather than leaking around the edges, as was simulated in the modeling for this report. This 
would provide a mechanism for moisture to penetrate to the depths found in drilling beneath the playa center, which could not be replicated by the vadose zone modeling using the leak-around conceptual model of this report.

\section{CONCLUSIONS}

Surface and subsurface modeling using data collected from the upper $40 \mathrm{~m}$ suggest that potential groundwater recharge may be occurring at crater U5a. Modeling simulations predicted that approximately $5,900 \mathrm{~m}^{3}$ of water had been captured by the crater and that approximately $5,200 \mathrm{~m}^{3}$ of water remained in the soil profile beneath the crater bottom and may be potential recharge. The term potential is used here to indicate that the water is not technically recharge because it has not yet reached the water table. The recharge rate is less certain due to uncertainty in the recharge surface area. The best estimates of annual average potential recharge rate lie between 36 and $118 \mathrm{~cm} \mathrm{year}^{-1}$ of water. In terms of basin-wide groundwater recharge in Frenchman Flat, where only a handful of craters exist, $5,200 \mathrm{~m}^{3}$ is not a significant volume and has a negligible effect on average recharge rates. However, water infiltrating through the bottoms of craters could introduce contaminants into the groundwater system hundreds of meters below the ground surface, though, modeling indicates that to date, water has not yet intersected the water table. Additionally, if contaminates are transported to the water table, the hydrology of Frenchman Flat is such that transport off of the NTS would likely require thousands of years.

The results obtained from this crater should be viewed as a worst case for potential groundwater recharge from craters, since U5a was selected for study based on its high recharge potential. Additionally, the vadose zone modeling was conducted to provide a worst-case estimate of recharge potential by restricting the lateral spread of the ponding events. Also, the late discovery of a thick silt-grained material beneath the crater surface would significantly slow the drainage of ponds around the edge of the current playa bottom and might even be sufficient to seal the crater from future deep infiltration except under extreme ponding conditions. Additional study of this deposit and the possible size and extent of the ponding event that deposited it would provide valuable information on the infiltration processes at the U5a crater.

\section{REFERENCES}

Bechtel Nevada, 1998. Hydrogeological characterization of the unsaturated zone at the Area 3 Radioactive Waste Management Site. U.S. Department of Energy, Nevada report number DOE/NV/11718-210, UC-721.

Carsel, R.F. and R.S. Parrish, 1988. Developing joint probability distributions of soil water retention characteristics. Water Resources Research, 24(5):755-769.

Crowe, B., W. Hansen, R.Waters, M. Sully and D. Levitt, 1998. The consequences of disposal of low-level radioactive waste from the Fernald Environmental Management Project: Report of the DOE/Nevada Independent Panel. Los Alamos National Lab, LA-13453-MS, UC-840. April 1998. 
Dawdy, D.R., 1979. Flood frequency estimates on alluvial fans. ASCE, Journal of the Hydraulics Division, 105(11):1407-1412.

French, R.H., R.L. Jacobson and B.F. Lyles, 1996. Threshold precipitation events and potential ground-water recharge. ASCE, Journal of Hydraulics Engineering, 11(10):573-578.

French, R.H., 1989. Effect of the length of record on estimates of annual precipitation in Nevada. ASCE, Journal of Hydraulic Engineering, 115(4):493-506.

French, R.H., 1987. Effects of the length of record on estimates of annual and seasonal precipitation at the Nevada Test Site, Nevada. DOE/NV/10384-18. Water Resources Center, Desert Research Institute, Las Vegas, Nevada.

French, R.H., 1983. Development of design hyetographs for southern Nevada. DOE/NV/1016211. Water Resources Center, Desert Research Institute, Las Vegas, Nevada

Hokett, S.L. and D.R. Gillespie, 1996. Preliminary evaluation of recharge potential at subsidence crater U5a in Frenchman Flat, Nevada Test Site. DOE/NV/11508-15. Water Resources Center, Desert Research Institute, Las Vegas, Nevada.

Hokett, S.L., 1995. Shallow soil moisture flux adjacent to Area 5 RWMS: Data Report. Letter report to the Department of Energy.

Lane, L.J. and W.R. Osterkamp, 1991. Estimated upland recharge in the Yucca Mountain area. ASCE, Irrigation and Drainage Proceedings, New York, pp. 170-176.

Magnuson, S.O., S.J. Maheras, H.D. Nguyen, A.S. Rood, J.I. Sipos, M.J. Case, M.A. McKenzieCarter and M.E. Donahue, 1992. Radiological performance assessment for the Area 5 Radioactive Waste Management Site at the Nevada Test Site. INEL, Idaho Falls, Idaho.

Press, W.H., B.R. Flannery, S.A. Teukolsky and W.T. Vettering, 1986. Numerical Recipes: The Art of Scientific Computing, Cambridge University Press, Cambridge, England.

Schmeltzer, J.S., J.J. Miller and D.L. Gustafson, 1993. Flood assessment at the Area 5 Radioactive Waste Management Site and the proposed hazardous waste storage unit, DOE/Nevada Test Site, Nye County, Nevada. Raytheon Services Nevada, Las Vegas, Nevada.

Shott, G.J., L.E. Barker, S.E. Rawlinson and M.J. Sully, 1997. Performance assessment for the Area 5 RWMS at the NTS, Nye County, Nevada. Bechtel Nevada. February 1997 - revision 2.1 .

Simunek, J. and M.Th. van Genuchten, 1996. Simulating water flow and solute transport in twodimensional variably saturated media. International Ground Water Modeling Center. IGWMC-TPS 53 
Tyler, S.W., J.B. Chapman, S.H. Conrad, D.P. Hammermeister, D.O. Blout, J.J. Miller, M.J. Sully and J.M. Ginanni, 1996. Soil-water flux in the southern Great Basin, United States: Temporal and spatial variations over the last 120,000 years. Water Resources Research, 32:1481-1499.

Tyler, S.W., W.A. Mckay and T.M. Mihevc, 1992. Assessment of soil moisture movement in nuclear subsidence craters. Journal of Hydrology, 139:159-181. 


\section{DISTRIBUTION}

Bob Bangerter

Environmental Restoration Division

Nevada Operations Office

U.S. Department of Energy

P.O. Box 98518

Las Vegas, NV 89193-8518

Joanne M. Bradbery, Director

Contract Management Division

Nevada Operations Office

U.S. Department of Energy

P.O. Box 98518

Las Vegas, NV 89193-8518

David Bedsun

Defense Special Weapons Agency

Field Command

Nevada Operations Office

P.O. Box 208

Mercury, NV 89023-0208

Rick Betteridge, Director

Technology Development Division

Nevada Operations Office

U.S. Department of Energy

P.O. Box 98518

Las Vegas, NV 89193-8518

Beverly Colbert

Contract Management Division

Nevada Operations Office

U.S. Department of Energy

P.O. Box 98518

Las Vegas, NV 89193-8518

Doug Duncan

Hydrology Program Manager

Environment, Safety \& Health Division

Nevada Operations Office

U.S. Department of Energy

P.O. Box 98518

Las Vegas, NV 89193-8518
Dennis Farmer

Radiation Sciences Laboratory

Office of Radiation and Indoor Air

U.S. Environmental Protection Agency

P.O. Box 98517, M/S 513

Las Vegas, NV 89193-8517

Larry Franks

Nevada State Health Department

Radiological Health Section

620 Belrose Avenue

Las Vegas, NV 89158

Kenneth Hoar, Director

Environment, Safety \& Health Division

Nevada Operations Office

U.S. Department of Energy

P.O. Box 98518

Las Vegas, NV 89193-8518

Kathy Izell

Assistant Manager for Technical Services

Nevada Operations Office

U.S. Department of Energy

P.O. Box 98518

Las Vegas, NV 89193-8518

Roger Jacobson

Water Resources Center

Desert Research Institute

755 E. Flamingo Road

Las Vegas, NV 89119

Marjory Jones

Water Resources Center

Desert Research Institute

7010 Dandini Blvd.

Reno, NV 89512

Randy Laczniak

Water Resources Division

U.S. Geological Survey

6770 S. Paradise Rd.

Las Vegas, NV 89119 
Steve Lawrence, Director

Engineering and Asset Management Division

Nevada Operations Office

U.S. Department of Energy

P.O. Box 98518

Las Vegas, NV 89193-8518

Steve Leedom

Stockpile Stewardship Division

Nevada Operations Office

U.S. Department of Energy

P.O. Box 98518

Las Vegas, NV 89193-8518

John McGrail, Director

STD

Nevada Operations Office

U.S. Department of Energy

P.O. Box 98518

Las Vegas, NV 89193-8518

Leslie A. Monroe

Environment, Safety \& Health Division

Nevada Operations Office

U.S. Department of Energy

P.O. Box 98518

Las Vegas, NV 89193-8518

Ken Ortego

Bechtel Nevada

P.O. Box 98521

Las Vegas, NV 89193-8521

Gayle Pawloski

Lawrence Livermore National Laboratory

P.O. Box 808 L-221

Livermore, CA 94551

Ken Rehfeldt

Geotrans, c/o IT

4330 Valley View

Suite 112, MS-439

Las Vegas, NV 89103

Mike Sabbe

Bechtel Nevada

P.O. Box 98521

Las Vegas, NV 89193-8521
David Shafer

Water Resources Center

Desert Research Institute

755 E. Flamingo Road

Las Vegas, NV 89119

David K. Smith

Isotopes Sciences Division

Lawrence Livermore National Laboratory

P.O. Box 808, M/S L231

Livermore, CA 94550

Joe Thompson

Los Alamos National Laboratory

INC-11, MS J514

P.O. Box 1663

Los Alamos, NM 87545

Doug Trudeau

U.S. Geological Survey

Water Resources Division

6770 S. Paradise Rd.

Las Vegas, NV 89119

Janet Wille

International Technology Corporation

P.O. Box 93838

Bldg. B-1, M/S 439

Las Vegas, NV 89103-3838

Vefa Yucel

Bechtel Nevada

P.O. Box 98521

Las Vegas, NV 89193-8521

Nevada State Library and Archives

State Publications

100 North Stewart Street

Carson City, NV 89701-4285

Archives

Getchell Library

University of Nevada, Reno

Beverly Carter

MacKay School of Mines Library

University of Nevada, Reno

Document Section, Library

University of Nevada, Las Vegas

4505 Maryland Parkway

Las Vegas, NV 89154 
Library (Stead)

Desert Research Institute

P.O. Box 60220

Reno, Nevada 89506-0220

Library

IT Corporation

Bldg. B-1

P.O. Box $93838, \mathrm{M} / \mathrm{S} 439$

Las Vegas, NV 89193-3838

ATTN: Toni Miller, M/S 439

Library

Southern Nevada Science Center

Desert Research Institute

P.O. Box 19040

Las Vegas, NV 89132-0040
Public Reading Facility

Nevada Operations Office

U.S. Department of Energy

P.O. Box 98521

Las Vegas, NV 89193-8521

Technical Information Resource Center

Nevada Operations Office

U.S. Department of Energy

P.O. Box 98518

Las Vegas, NV 89193-8518

Librarian

Water Resources Center Archives

410 O`Brien Hall

University of California

Berkeley, CA 94720-1718

Office of Scientific and Technical Information U.S. Department of Energy

P.O. Box 62

Oak Ridge, TN 37831-9939 